\title{
Patterns of woodboring beetle activity following fires and bark beetle outbreaks in montane forests of California, USA
}

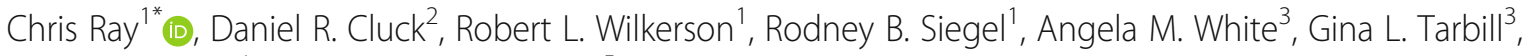
Sarah C. Sawyer ${ }^{4}$ and Christine A. Howell ${ }^{5}$

\begin{abstract}
Background: Increasingly frequent and severe drought in the western United States has contributed to more frequent and severe wildfires, longer fire seasons, and more frequent bark beetle outbreaks that kill large numbers of trees. Climate change is expected to perpetuate these trends, especially in montane ecosystems, calling for improved strategies for managing Western forests and conserving the wildlife that they support. Woodboring beetles (e.g., Buprestidae and Cerambycidae) colonize dead and weakened trees and speed succession of habitats altered by fire or bark beetles, while serving as prey for some early-seral habitat specialists, including several woodpecker species. To understand how these ecologically important beetles respond to different sources of tree mortality, we sampled woodborers in 16 sites affected by wildfire or bark beetle outbreak in the previous one to eight years. Study sites were located in the Sierra Nevada, Modoc Plateau, Warner Mountains, and southern Cascades of California, USA. We used generalized linear mixed models to evaluate hypotheses concerning the response of woodboring beetles to disturbance type, severity, and timing; forest stand composition and structure; and tree characteristics.

Results: Woodborer activity was often similar in burned and bark beetle outbreak sites, tempered by localized responses to bark beetle activity, burn severity, tree characteristics, and apparent response to ignition date. Larval woodborer activity was inversely related to bark beetle sign within a sampling quadrat, was higher on pines, and -in burned sites — was higher on the south-facing sides of smaller trees. Adults-especially buprestids - were more abundant where burn severity was higher. Fires with intermediate ignition dates during the study period supported higher rates of larval woodborer activity and higher numbers of adult buprestids as well as cerambycids in the genus Monochamus Dejean 1821.

Conclusions: Woodboring beetle abundance was related to bark beetle activity, burn severity, tree characteristics, and ignition date. Considering these patterns when managing disturbed forest stands could yield improved outcomes for wildlife, including species that prey on woodboring beetles. We also reported preliminary evidence that the current trend toward more frequent wildfires might not stimulate larger woodboring beetle populations if those fires increasingly occur outside the historical fire season.
\end{abstract}

Keywords: Buprestidae, burn severity, Cerambycidae, fire season, forest management, Scolytinae, snags, succession, wildfire, woodborers

\footnotetext{
* Correspondence: cray@birdpop.org

${ }^{1}$ The Institute for Bird Populations, P.O. Box 1346, Point Reyes Station,

California 94956, USA

Full list of author information is available at the end of the article
} 


\section{Resumen}

Antecedentes: El aumento frecuente y severo de sequías en el oeste de los EEUU ha contribuido a incrementar la frecuencia y severidad de los incendios forestales, el alargamiento de la temporada de estos y el incremento de brotes de escarabajos descortezadores que matan un gran número de árboles. Se espera que el cambio climático perpetúe estas tendencias, especialmente en ecosistemas montañosos, lo que llama a mejorar las estrategias para el manejo de los bosques del oeste de los EEUU y conservar la vida silvestre que estos sostienen. Los escarabajos barrenadores (i.e., Buprestidae y Cerambycidae) colonizan árboles muertos y débiles y aceleran la sucesión secundaria en hábitats alterados por fuego o por escarabajos descortezadores; al mismo tiempo, sirven de presa para algunos especialistas que actúan durante las etapas tempranas de la sucesión, incluyendo diferentes especies de pájaros carpinteros. Para entender ecológicamente cómo los escarabajos barrenadores responden a las diferentes causas de mortalidad de árboles, estos fueron muestreados en 16 sitios afectados en 16 sitios afectados por incendios o por brotes de escarabajos descortezadores ocurridos de uno a ocho años antes. Los sitios de estudio se ubicaron en la Sierra Nevada, en el Plateau Modoc, en las montañas Warner y las Cascadas del Sur de California, EEUU. Se usaron modelos mixtos lineales generalizados para evaluar las hipótesis concernientes a la Respuesta de los escarabajos barrenadores al tipo de disturbio, severidad, tiempo de ocurrencia, la composición del rodal y su estructura, y las características de los árboles.

Resultados: La actividad de los barrenadores fue frecuentemente similar en áreas quemadas y en sitios que presentaron brotes de escarabajos descortezadores, y atemperada por respuestas localizadas por la actividad de escarabajos descortezadores, la severidad de los incendios, las características de los árboles, y la aparente respuesta a la fecha de ignición. La actividad de las larvas de barrenadores presento una relación inversa a la presencia de escarabajos descortezadores dentro de un cuadrante de muestreo; esta relación fue más alta en pinos y en los lados con orientación sur de árboles pequeños en los sitios quemados. Los adultos de la familia Buprestidae fueron más abundantes donde la severidad del incendio fue mayor. Los incendios con fechas de ignición intermedias durante el período de estudio mantuvieron mayores tasas de actividad larval de barrenadores y mayores números de bupréstidos adultos como así también de cerambícidos del género Monochamus Dejean 1821.

Conclusiones: La abundancia de los escarabajos barrenadores estuvo relacionada con la actividad de escarabajos descortezdores, la severidad del incendio, las características de los árboles, y la fecha de ignición. Considerar estos patrones cuando se manejan rodales perturbados puede beneficiar a la vida silvestre; incluyendo a aquellas especies que presan sobre escarabajos barrenadores. Así mismo, reportamos evidencia preliminar que la tendencia actual hacia incendios forestales más frecuentes podría no estimular mayores poblaciones de escarabajos barrenadores si estos incendios forestales ocurren de manera incremental fuera del lapso histórico de la temporado de estos.

\section{Abbreviations}

AIC: Akaike's information criterion

BA: basal area

BBO: bark beetle outbreak

BUPR: buprestids

CERA: cerambycids

CWHR: California Wildlife Habitat Relationships

DBH: diameter at breast height

DOY: day of year

EPN: Eastside Pine (forest)

MECO: Melanophila consputa

MONO: Monochamus species

RdNBR: Relative differenced Normalized Burn Ratio

SE: standard error

SMC: Sierran Mixed Conifer (forest)

QAIC: quasi-AIC (see AIC)
VRP: variable radius plot

\section{Background}

Forests in the western United States have entered a period of intensifying disturbance. Drought years have become increasingly common and severe, and projected changes in precipitation are expected to exacerbate these trends (Seager et al. 2007; Diffenbaugh et al. 2015). Severe drought and increasing temperatures leave forests drier and more susceptible to bark beetle (Coleoptera: Scolytinae) outbreaks triggered by the lower resistance of drought-stressed trees (Bentz et al. 2010; Williams et al. 2013; Kolb et al. 2016; Marini et al. 2017). The frequency and area of large fires (Littell et al. 2009; Dennison et al. 2014), as well as fire-season length (Westerling et al. 2006; Westerling 2016), have increased in recent decades across the western US, where forest fires are 
expected to become more common in response to predicted changes in climate, especially in montane forests (Abatzoglou and Williams 2016). Larger and more severe wildfires have been facilitated by increased forest density, fuel loading, and the loss of forest heterogeneity resulting from fire exclusion (Miller et al. 2009a; Taylor et al. 2014; Boisramé et al. 2016). Over the next two decades, as many as 11 states in the western US might see the average annual area burned increase by 500 percent (Kitzberger et al. 2017), and temperature-driven models indicate that there is potential for extensive bark beetle outbreaks in forests of the western US throughout this century (Raffa et al. 2008; Bentz et al. 2010). The increase in tree mortality resulting from these large and frequent disturbances is expected to provide abundant habitat for woodboring beetles that typically colonize trees killed or weakened by other agents (Cranshaw et al. 2000). Many woodboring beetles aid decomposition and nutrient recycling in disturbed forest stands (Jacobsen et al. 2015; Kahl et al. 2017). Understanding how woodborers respond to different types of forest disturbance and stand characteristics will be important for predicting the response of forest communities to changes in the disturbance regime.

Woodboring beetle families Cerambycidae and Buprestidae contain hundreds of species, many of which are common and widespread throughout coniferous forests of the western US. As reviewed in Furniss and Carolin (1977), most woodboring beetles are considered secondary forest pests because they generally colonize trees already killed or weakened by disturbance, including wildfire, blowdown, timber harvest activities, and outbreaks of primary forest pests such as "primary" bark beetles that can kill healthy trees. In trees colonized by bark beetles, the spatial distribution of woodborer and bark beetle larvae is sometimes disjunct, and there is some evidence of competition for phloem between species within trees (Coulson et al. 1976; Foelker et al. 2018), as well as some evidence that woodboring larvae consume bark beetle larvae (Dodds et al. 2001). Larval woodborers feed within the cambium layer during early development (Fig. 1) and later tunnel into sapwood and heartwood. Their tunneling introduces fungi that reduce the economic value of harvested timber but also facilitate the decomposition of dead wood, recycling nutrients and reducing fuel loads (Harrington 1993; Lowell and Cahill 1996). The life cycle of both cerambycid and buprestid beetles is dominated by the larval stage, which typically lasts one year but can extend to several years (Kariyanna et al. 2017). Adults emerge and fly during the warmer months, seeking out recently dead or weakened trees. Most woodborers are unable to attack healthy trees and are more often attracted to trees that release chemical signals of stress (Ikeda et al. 1980; Kelsey and Joseph 2003; Miller 2006). Some woodborers locate burned trees by sensing heat or smoke (Schmitz et al. 1997; Schütz et al. 1999; Âlvarez et al. 2015). Females deposit eggs in bark crevices, under bark scales, or in small niches cut into the bark, and have been observed to avoid oviposition where bark beetle activity is high (Gardiner 1957).

Research on woodboring beetles has concentrated primarily on native species that cause damage to wood products (Álvarez et al. 2015) or exotic and invasive species that disrupt entire ecosystems (Aukema et al. 2010; Aukema et al. 2011). Much less is known about how native woodboring beetles colonize and use trees damaged by fire and primary bark beetles, and how woodborers respond to the timing and severity of disturbance, forest composition and structure, host tree attributes, and interspecific competition (Costello et al. 2011; Costello

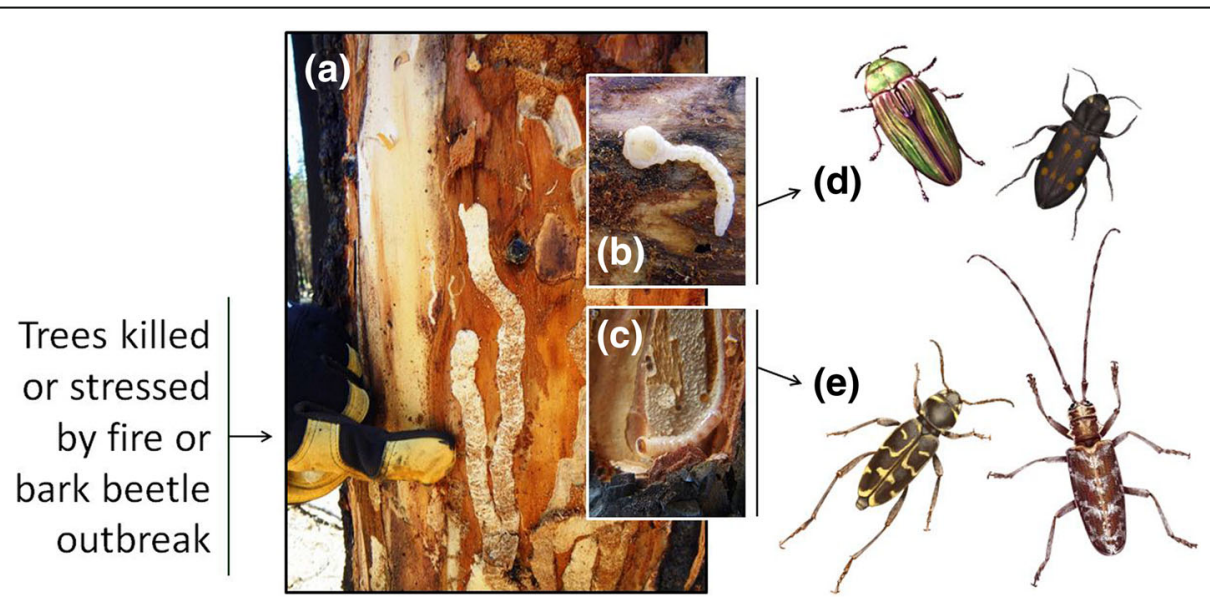

Fig. 1 Galleries of woodboring beetle larvae exposed in a bark sample (a). Flat-headed woodborers (b) are the larvae of buprestid or jewel beetle adults (d), and round-headed woodborers (c) are the larvae of cerambycid or longhorn beetle adults (e). Buprestid species shown (d) are Cypriacis aurulenta (left) and Melanophila consputa (right). Cerambycid species shown (e) are Xylotrechus longitarsus (left) and Monochamus obtusus (right). Photos (a, b, and $\mathbf{c})$ by D.R. Cluck. Illustrations ( $\mathbf{d}$ and $\mathbf{e})$ by Lauren Helton 
2013; Brin and Bouget 2018). Given the observed potential for ecological and economic impacts of many woodborer species, characterizing these responses could inform management of disturbed forests. Management of post-disturbance forests often involves multiple objectives, such as recovering the economic value of dead trees (Eklund et al. 2009), mitigating hazards associated with disturbance, facilitating reforestation (Collins and Roller 2013; Bohlman et al. 2016), reducing fuel levels and the risk of type conversion (Coppoletta et al. 2016), and providing a diversity of wildlife habitats (White et al. 2015). Achieving these objectives might be facilitated by manipulating woodborer impacts on woody fuel decomposition, nutrient cycling, and succession, as well as increasing the availability of woodboring larvae as prey for early-seral habitat specialists. For example, the blackbacked woodpecker (Picoides arcticus Swainson, 1832) is a species of management interest (Saracco et al. 2011; Siegel et al. 2018) that feeds primarily on the larvae of woodboring beetles (Villard and Beninger 1993; Murphy and Lehnhausen 1998). Relative to bark beetles, woodborer larvae are larger and provide a more concentrated prey resource (Powell 2000).

To inform forest management strategies designed to maintain processes dependent on woodborers, we characterized woodborer activity in 16 sites representing 11 wildfires and five bark beetle outbreaks. We tested several hypotheses (Table 1) regarding important controls on woodborer activity, based on our own experiences in the field as well as previous research on these species (e.g., Costello et al. 2011; Costello 2013). In general, our hypotheses address processes that we expected to affect the activity (abundance) of both larval and adult woodborers, under the simplifying assumption that processes affecting one life stage should result in similar effects on the subsequent stage or generation. However, we conducted separate analyses of larvae and several adult taxa to differentiate responses by stage and taxon. Our results represent the first characterization of woodborer response to disturbance type and stand conditions across multiple forests in California.

\section{Methods}

\section{Site selection}

During the summers of 2015 and 2016, we sampled 11 burned sites and five bark beetle outbreak (BBO) sites in the greater Sierra Nevada region of California, USA (Fig. 2), including the physiographic Sierra Nevada, Modoc Plateau, Warner Mountains, and southern Cascades. Sierran Mixed Conifer (SMC) and Eastside Pine (EPN) (California Department of Fish and Game 2005) forests were selected for sampling due to their common occurrence in the study region, and variety of constituent tree species. SMC forests typically consist of white fir (Abies concolor [Gordon and Glendinning] Lindley ex Hildebrand), Douglas-fir (Pseudotsuga menziesii [Mirb] Franco), ponderosa pine (Pinus ponderosa Douglas ex C.Lawson), sugar pine (Pinus lambertiana Douglas), incense-cedar (Calocedras decurrens [Torrey] Florin), and California black oak (Quercus kelloggii Newb). EPN forests consist of ponderosa pine with less representation by Jeffrey pine (Pinus jeffreyi A.Murray bis), lodgepole pine (Pinus contorta Douglas ex Loudon), white fir,

Table 1 Non-exclusive, alternative hypotheses $\left(H_{A}\right)$ regarding processes expected to affect the activity (abundance) of larval or adult woodboring beetles that colonize trees killed or weakened by wildfire or bark beetle outbreak (BBO). These hypotheses were addressed with respect to five BBO sites and 11 burned sites that were sampled in the greater Sierra Nevada region of California, USA, during the summers of 2015 and 2016

$\mathrm{H}_{\mathrm{A}}$ Process

$\mathrm{T}$ Type of disturbance: Woodborer activity is higher in burned than BBO stands because heat and smoke attract some woodborer taxa and because fire can create a pulse of resources (dead and weakened trees) not previously exploited by bark beetles.

M Magnitude of disturbance: Woodborer activity is higher where dead trees are more abundant, due to the attractiveness of a large resource base.

S Severity of disturbance: Woodborer activity is higher in stands burned at higher severity because more severe fires produce more smoke and heat as well as more dead and dying trees. Outbreak severity also affects woodborer activity, through positive effects on resource production and negative effects of increased interspecific competition.

A Age of disturbance: Woodborer activity eventually declines with time after a disturbance, as the resource is depleted. Conversely, the activity of larval woodborers increases within the first year or two after a disturbance, as eggs continue to be deposited and larvae grow.

P Phenology: Woodborer activity is lower in stands that ignite early or late in the fire season, if most adults disperse during the middle of the fire season when ignitions are most frequent.

H Host quality: Woodborer activity varies by tree taxon due to taxon-specific differences in the quality of trees as a host resource.

G Growth rate: Woodborer activity is higher on the southern sides of smaller snags (standing dead trees) in locations where diurnal warming can facilitate larval growth.

C Competition: At scales appropriate to each life stage, woodborer activity varies inversely with bark beetle activity, due to adult host preferences and larval competition for phloem. 

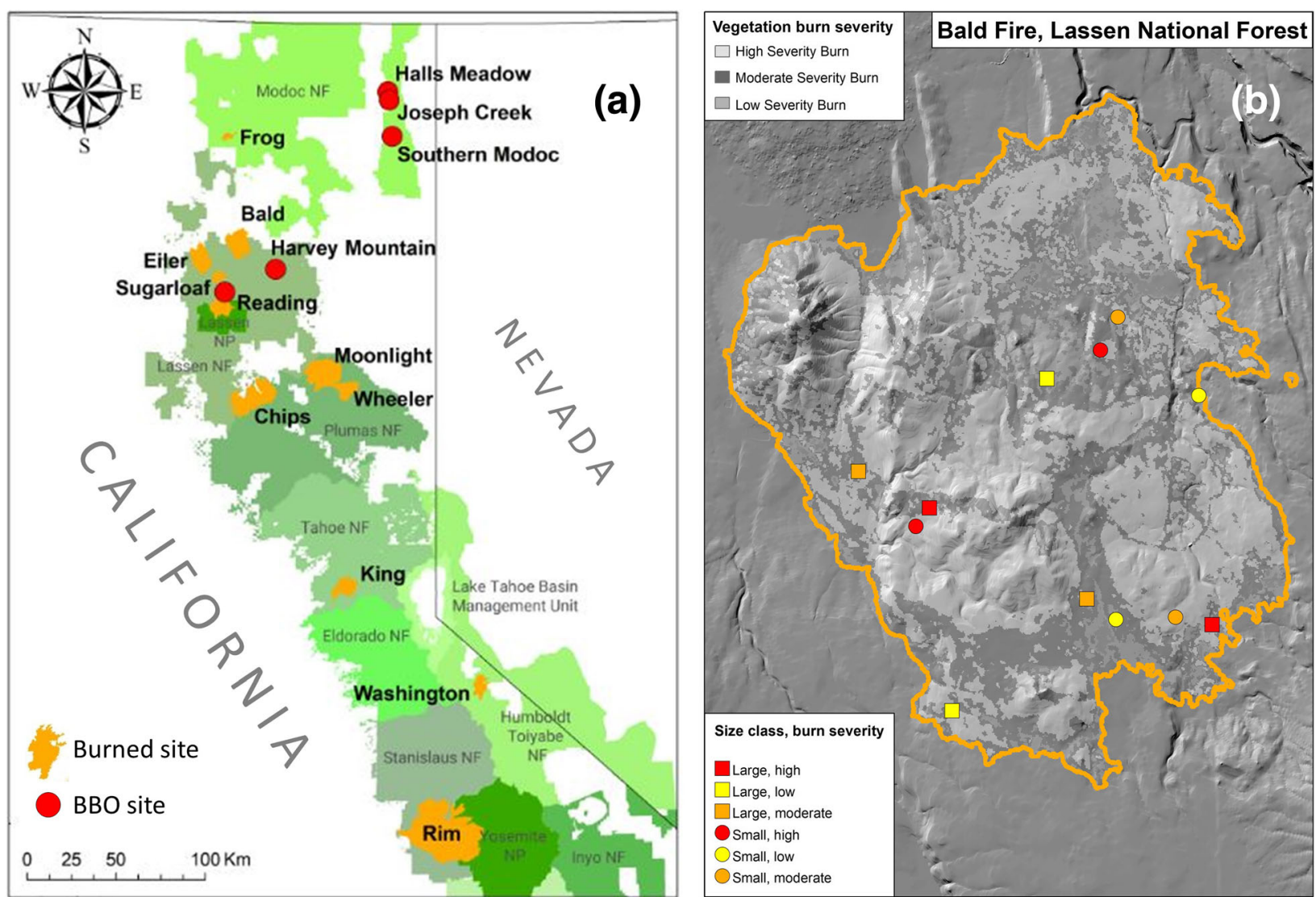

Fig. 2 Study sites (a) previously burned by wildfire $(n=11)$ or attacked by bark beetles $(n=5)$ were sampled during the summers of 2015 and 2016 in national forests (NF) throughout California's Sierra Nevada, Modoc Plateau, Warner Mountains, and California Cascades, USA. The Reading area included a burned site and an unburned bark beetle outbreak (BBO) site. A typical sampling design is shown for the Bald Fire site (b), in which 12 transects (of three plots each) were distributed in a stratified random design to sample two stands of larger trees and two stands of smaller trees within each of three levels of burn severity (Table 1). Darker gray shading indicates topographic relief (b), including lower (darker) and higher (lighter) elevations, while lighter gray shading indicates burn severity within the fire boundary (see legend)

incense-cedar, Douglas-fir, California black oak, and western juniper (Juniperus occidentalis Hooker).

We selected sampling sites non-randomly, based on specific criteria and logistical concerns. All sites were selected prior to 2016, before large bark beetle outbreaks became evident in the southern Sierra Nevada. Burned and BBO sites were situated mainly in Plumas, Lassen, and Modoc national forests for easy access by our primary field crew, augmented by additional burned sites within the King, Washington, and Rim fires that were accessible by a secondary field crew (Fig. 2a). Burned sites (Table 2) were selected from fires that occurred throughout the prior decade and that burned enough forest on national forest land to accommodate 12 sampling transects (Fig. 2b). BBO sites (Table 3) were smaller and accommodated fewer transects.

To guide transect placement, we used several spatial data products (Additional file 1, a through g) to exclude areas (a) on private property, (b) with slopes exceeding $30 \%$, (c) more than $250 \mathrm{~m}$ from roads, or d) where post-disturbance logging had occurred; and to include only areas (e) within targeted forest types (SMC or EPN), and within either (f) mapped wildfire boundaries, or $(\mathrm{g})$ areas with a high density of trees $\left(>50 \mathrm{ha}^{-1}\right)$ killed by bark beetles in the year prior to BBO site surveys. The remaining area was stratified by the dominant (predisturbance) tree size class (Additional file 1, e). Using California Wildlife Habitat Relationships (CWHR) classifications (California Department of Fish and Game 2005), we focused our study on trees in two size classes: class 3 trees (15 to $28 \mathrm{~cm}$ in diameter at breast height $[\mathrm{DBH}])$, and classes 4 and 5 trees ( $>28 \mathrm{~cm} \mathrm{DBH})$.

In burned sites, burn severity was classified as low, moderate, or high (Additional file 1, f) based on a Relative differenced Normalized Burn Ratio (RdNBR) calculated from pre- and post-fire imagery and calibrated using the Composite Burn Index (Miller et al. 2009b; Miller and Quayle 2015). Within each fire's perimeter, transects were positioned randomly among the available levels of our two focal tree size classes and three burn 
Table 2 Characteristics of 11 burned sites sampled in the greater Sierra Nevada region of California, USA, during the summers of 2015 and 2016, including the date on which each wildfire ignited (Ignition date)

\begin{tabular}{|c|c|c|c|c|c|c|}
\hline \multirow[b]{2}{*}{ Burned site (fire name) } & \multirow[b]{2}{*}{ National forest } & \multirow[b]{2}{*}{$\operatorname{Area}^{\mathrm{a}}$ (ha) } & \multirow[b]{2}{*}{ Ignition date } & \multicolumn{3}{|c|}{ Survey } \\
\hline & & & & Year & Transects $(n)$ & Elevation (m) \\
\hline Wheeler & Plumas & 9484 & 5 Jul 2007 & 2015 & 12 & $1588-1726$ \\
\hline Moonlight & Plumas & 26509 & 3 Sep 2007 & 2015 & 12 & $1565-2016$ \\
\hline Sugarloaf & Lassen & 3897 & 1 Aug 2009 & 2015 & 11 & $1225-1590$ \\
\hline \multirow[t]{2}{*}{ Reading $^{b}$} & Lassen & 11478 & $23 \mathrm{Jul} 2012$ & 2015 & 12 & 1659-2003 \\
\hline & & & & 2016 & 12 & $1669-2162$ \\
\hline Chips & Plumas and Lassen & 31210 & $28 \mathrm{Jul} 2012$ & 2016 & 12 & $1221-1834$ \\
\hline Rim & Stanislaus & 104460 & 17 Aug 2013 & 2015 & 12 & $1160-2073$ \\
\hline Bald & Lassen & 16258 & $30 \mathrm{Jul} 2014$ & 2016 & 12 & $1269-1599$ \\
\hline Eiler & Lassen & 13624 & $31 \mathrm{Jul} 2014$ & 2015 & 10 & $1154-1715$ \\
\hline King & Eldorado & 39843 & 13 Sep 2014 & 2015 & 12 & $1362-2206$ \\
\hline Washington & Humboldt-Toiyabe & 7444 & 19 Jul 2015 & 2016 & 6 & $1866-2050$ \\
\hline Frog & Modoc & 2036 & $30 \mathrm{Jul} 2015$ & 2016 & 6 & $1340-1358$ \\
\hline
\end{tabular}

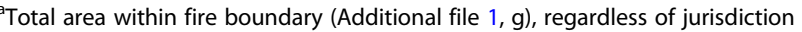

${ }^{\mathrm{b}} n=24$ separate transects sampled during 2015 and 2016

severities; in most cases, 12 transects were positioned in order to sample two stands of smaller trees and two stands of larger trees within each available level of burn severity. In some cases, some combinations of size class and burn severity were limited or unavailable within a fire boundary, resulting in fewer transects at those sites (Table 2).

BBO sites (Table 3) were dominated by white fir killed by fir engraver beetle (Scolytus ventralis LeConte), but also featured ponderosa pine killed by western pine beetle (Dendroctonus brevicomis LeConte) or Jeffrey pine killed by Jeffrey pine beetle (Dendroctonus jeffreyi Hopkins). Random transect positions in BBO sites were stratified by tree size class but not by severity of disturbance because the density of trees killed by bark beetles continued to increase unevenly across areas suitable for transect placement before our sampling could begin.

Table $\mathbf{3}$ Characteristics of five bark beetle outbreak sites sampled in the greater Sierra Nevada region of California, USA, during the summer of 2016

\begin{tabular}{|c|c|c|c|c|c|}
\hline \multirow[b]{2}{*}{$\mathrm{BBO}$ site } & \multirow[b]{2}{*}{$\begin{array}{l}\text { National } \\
\text { forest }\end{array}$} & \multirow[b]{2}{*}{$\begin{array}{l}\text { Area }^{a} \\
\text { (ha) }\end{array}$} & \multicolumn{3}{|c|}{ Survey } \\
\hline & & & Year & $\begin{array}{l}\text { Transects } \\
\text { (n) }\end{array}$ & $\begin{array}{l}\text { Elevations } \\
\text { (m) }\end{array}$ \\
\hline Harvey Mountain & Lassen & 1162 & 2016 & 4 & 1967-2046 \\
\hline Reading $^{\mathrm{b}}$ & Lassen & 795 & 2016 & 9 & $1418-1619$ \\
\hline Halls Meadow & Modoc & 542 & 2016 & 6 & 1797-1908 \\
\hline Joseph Creek & Modoc & 403 & 2016 & 8 & 1698-1907 \\
\hline Southern Modoc & Modoc & 245 & 2016 & 3 & 1710-2087 \\
\hline
\end{tabular}

Total area of 2015 Aerial Detection Survey polygons per site (see Additional file 1, g)

${ }^{\mathrm{b}}$ Adjacent to the Reading Fire but unburned

\section{Data collection}

We established 159 transects (Tables 2 and 3), each $100 \mathrm{~m}$ long and aligned with a cardinal or inter-cardinal azimuth selected to fall within the defined tree size class and (if applicable) burn severity polygon. Each transect consisted of three plots $(n=477$ total). Plot centers were established at 0,50 , and $100 \mathrm{~m}$ along each transect.

Larval activity and adult activity (Table 4 ) were selected as response variables for statistical modeling, and were measured at scales appropriate to each life stage. Adult woodborer activity was sampled at the plot scale using unbaited traps to avoid influencing the beetles' natural distribution. Each plot contained one panel trap (Alpha Scents, Inc., West Linn, Oregon, USA), mounted on a metal pole near the plot center and positioned at least $2 \mathrm{~m}$ from any tree. Traps were lubricated with Fluon (AGC Chemicals, Exton, Pennsylvania, USA), and each contained a pest strip in its collection cup. Traps were emptied every two weeks (mean $=13.98 \pm 0.12$ days), and remained in place for nearly eight weeks (52.65 \pm 0.39 days) during June through August, the period of peak woodborer flight in the greater Sierra Nevada (D.R. Cluck, USDA Forest Service, Forest Health Protection, Susanville, California, USA, unpublished data).

Larval woodborer activity (Table 4) was sampled in bark quadrats on the north and south sides of up to 6 $(5.19 \pm 0.09)$ of the closest snags within $25 \mathrm{~m}$ of each trap or plot center. Bark quadrats were $15 \mathrm{~cm} \times 15 \mathrm{~cm}$ and were positioned at breast height $(1.37 \mathrm{~m})$ in snags with at least one side suitable for larval sampling (bark attached or sapwood surface intact) (Powell et al. 2002). We placed quadrats in trees of a representative size by targeting snags 15 to $40 \mathrm{~cm} \mathrm{DBH}$ where trees were in 
Table 4 Response variable definitions for the two life stages of woodboring beetles analyzed in this study of 11 burned sites and five bark beetle outbreak sites sampled in the greater Sierra Nevada region of California, USA, during the summers of 2015 and 2016 Response Definition

Larval activity

Abundance of larval woodborer sign within a bark sampling quadrat, scored as 0 to 4 based on presence or absence of sign in each of four sub-quadrats

Adult activity Number of adult woodborers (by taxon) captured per trap-visit within a plot

size class 3 , and snags $>40 \mathrm{~cm} \mathrm{DBH}$ where trees were in size classes 4 and 5 . Each quarter of each quadrat was scored separately for presence (1) or absence (0) of larval woodborer activity, including living or dead specimens and characteristic frass or boring dust, exit or transit holes, or galleries on any part of the quarter-quadrat, including the sapwood surface, bark interior, or (except frass or boring dust) bark exterior (Furniss and Carolin 1977).

Larvae collected from quadrats were stored in vials and identified to family, while adults collected from traps were sealed in plastic bags and identified to species, genus, or family using reference collections (USDA Forest Service, Forest Health Protection, Reference Insect Collection, Susanville, California, USA), online resources (http://www.mtent.org/projects/woodboring/index.html), identification keys (Furniss and Carolin 1977, Arnett Jr. et al. 2002, Evans and Hogue 2006, Schiff et al. 2006, LaBonte et al. 2013a, LaBonte et al. 2013b), and consultation with Oregon Department of Agriculture for identification of Melanophila Eschscholtz 1829 species. Non-target insects captured in traps were generally identified to family.

Bark quadrats used for sampling larval woodborers were also used to quantify several tree characteristics that were targeted as potential predictors of woodborer activity (detailed in Table 5). Each full quadrat was scored for bark condition, char depth (Ryan 1982), and bark beetle activity (characteristic pitch tubes and other taxon-specific signs as listed above for woodboring larvae). Snags sampled via quadrat were also identified to species; measured for $\mathrm{DBH}$, height, char height, and percent needles retained; and examined for broken top.

To quantify predictor variables related to stand characteristics (Table 5), we established a variable-radius plot (VRP) centered on each trap. We used a slope-compensating angle gauge to count trees $\geq 10 \mathrm{~cm}$ $\mathrm{DBH}$, and estimated stand basal area $\left(\mathrm{m}^{2} \mathrm{ha}^{-1}\right)$ from stem counts using a basal area factor of 10 or 20. For each stem counted within the VRP, we also recorded species and status (live or dead).

Predictors related to geographic gradients (Table 5) were calculated using a digital elevation model (Additional file 1). Elevation was adjusted by $130.1 \mathrm{~m}$ per degree of latitude, to account for the declining elevation of tree line with latitude in California (Brock and Inman 2006; Tingley and Beissinger 2013).

\section{Data analyses}

We tested our focal hypotheses (Table 1) using an information-theoretic approach, fitting a set of alternative models for each response (Table 4) based on one to four fixed effects and selected interactions drawn from our list of potential predictor variables (Table 5). Response variables measured in burned sites were modeled separately from those in BBO sites, to address hypotheses regarding the effects of ignition date and burn severity not applicable in unburned sites. Mixed-effects multiple regression was used to account for the random effects in this system (Table 5), including spatial dependence among samples and repeated measures at each trap. Larval activity was modeled as a binomial process, and support for each larval model was ranked with respect to a null (random effects) model using AICc, an information criterion corrected for sample size (Burnham and Anderson 2002). Adult activity was modeled as a Poisson process adjusted for over-dispersion, and each adult model was ranked using QAICc (Burnham and Anderson 2002). For each numeric predictor variable $x$, $x_{i}$ (ith value of $x$ ) was standardized by subtracting the mean of $x$ and dividing by the standard deviation of $x$. Multicollinearity among fixed effects was avoided by screening predictor variables for high pairwise correlations (Kendall's tau > 0.5), or by replacing a predictor variable with the residual of its linear regression on a correlated predictor (following Graham 2003).

We reported the relative support for models using both (a) $\Delta$ (Q)AICc = focal model (Q)AICc - minimum (Q)AICc across each candidate model set, and (b) $\Delta_{\text {Null }}=$ null model (Q)AICc - focal model (Q)AICc. We assumed that $\Delta(\mathrm{Q})$ AICc $>2$ indicated models with lower support than the top model, while (by extension) $\Delta_{\text {Null }}>2$ indicated models with higher support than the null model. We also summarized key data and results using means \pm standard errors (SE), and adopted $\alpha=0.05$ as our threshold for determining the significance of $P$-values. All analyses were conducted using the $\mathrm{R}$ environment for statistical computing ( $\mathrm{R}$ Core Team 2016), and mixed-effect models were fit using package lme4 (Bates et al. 2015).

\section{Results}

Patterns in potential covariates of woodborer activity

We measured 5683 trees (43\% of which were snags) across our variable-radius plots, including 1683 white fir, 1268 ponderosa pine, 1265 Jeffrey pine, 568 
Table 5 Predictor variable definitions and associated hypotheses $\left(\mathrm{H}_{\mathrm{A}}\right.$ from Table 1$)$ regarding woodborer response to disturbance severity $(S)$, magnitude $(M)$, age $(A)$, and phenology $(P)$, as well as host quality $(H)$ and factors affecting or indicating the potential for larval growth $(\mathrm{G})$ and interspecific competition (C). Values for each predictor variable in this study were drawn from 11 burned or five bark beetle outbreak sites sampled in the greater Sierra Nevada region during the summers of 2015 and 2016 . RdNBR $=$ Relative differenced Normalized Burn Ratio, BA = basal area, VRP = variable-radius plot, DOY = day of year, DBH = diameter at breast height, $\mathrm{CWHR}=$ California Wildlife Habitat Relationships

\begin{tabular}{|c|c|c|}
\hline Predictor & Definition and unit of measurement & $\mathrm{H}_{\mathrm{A}}$ \\
\hline Bark beetle activity & Bark beetle sign (present $=1$, absent $=0$ ) within a bark sampling quadrat ${ }^{\mathrm{a}}$ & C \\
\hline Burn severity ${ }^{b}$ & RdNBR class (low, moderate, high) at the transect level & S \\
\hline Char depth & $\begin{array}{l}\text { Bark char depth class (deep }=3 \text {, moderate }=2 \text {, light }=1 \text {, unburned }=0 \text {, bark missing }=N A \text { ) within a bark sampling } \\
\text { quadrat }^{\mathrm{a}}\end{array}$ & S \\
\hline Char height & Mean of two measures of maximum height $(\mathrm{m})$ of char on a tree ${ }^{\mathrm{a}}$ & S \\
\hline Snag BA ratio & Snag BA : total BA (unitless) within a VRP & S \\
\hline Snag BA & Dead tree basal area $\left(\mathrm{m}^{2} \mathrm{ha}^{-1}\right)$ within a VRP & $\begin{array}{l}M, \\
S\end{array}$ \\
\hline Live tree BA & Live tree basal area $\left(\mathrm{m}^{2} \mathrm{ha}^{-1}\right)$ within a VRP & $\begin{array}{l}M, \\
S\end{array}$ \\
\hline Needles retained & Percent of needles (estimated in $5 \%$ increments) retained on a tree ${ }^{a}$ & A \\
\hline Fire age & Time $(y r)$ since ignition of a burned site & A \\
\hline Bark condition & General condition (tight, loose, missing) of bark within a quadrat & A \\
\hline Broken-top tree & Top of tree is broken or missing (true, false) ${ }^{a}$ & A \\
\hline Ignition date & DOY of site-level ignition and its nonlinear effect (DOY × DOY) & $\mathrm{P}$ \\
\hline Host tree taxon & Taxon (yellow pine, true fir, or incense-cedar) of a tree & $\mathrm{H}$ \\
\hline Tree size ${ }^{b}$ & Small (13-28 cm DBH $=$ CWHR size class 3 ) or large (>28 cm DBH $=$ CWHR size classes 4 and 5$)$ & G \\
\hline $\mathrm{DBH}$ & Diameter $(\mathrm{cm})$ at breast height of a tree ${ }^{a}$ & G \\
\hline Height & Maximum vertical height $(m)$ of a tree ${ }^{a}$ & G \\
\hline Bark aspect ${ }^{\mathrm{b}}$ & Aspect (northern or southern exposure) of a bark-sampling quadrat & G \\
\hline Elevation & Latitude-adjusted plot elevation $(m)$ and its nonlinear effect $\left(m^{2}\right)$ & G \\
\hline Latitude, longitude & Coordinates of plot position (UTM WGS 84) & G \\
\hline Year $^{\mathrm{b}}$ & Sampling year for the site & \\
\hline Random effects ${ }^{\mathrm{b}}$ & Site, transect, plot, and tree & \\
\hline
\end{tabular}

${ }^{a}$ For models of adult woodborer activity, sub-plot data were averaged at the plot level, except bark condition and aspect (not used in adult models) and host tree taxon (replaced by dominant host tree taxon in each plot).

${ }^{\mathrm{b}}$ Study design variables

incense-cedar, and several less common taxa. Yellow pines dominated in burned sites and white fir dominated in BBO sites (Table 6). Basal area (BA) of all trees (live and dead) calculated at the plot level and averaged at the transect level was significantly higher at BBO sites, while snag BA was significantly higher at burned sites. Tree size class and BA were correlated at the transect level (Kendall's tau $=0.13, P=0.041$ ), but the measured size of trees averaged at the transect level did not differ between site types (Table 6).

In the subset of snags sampled for larval activity and additional covariates, mean DBH was slightly lower in burned sites (Table 6), which contained very few snags in the small size class. A similar proportion of trees were snags, regardless of size class: snag proportion was $0.50 \pm 0.05$ in stands of larger trees and $0.49 \pm 0.05$ in stands of smaller trees. Bark beetle sign was found in nearly one third and over two thirds, respectively, of quadrats in burned and BBO sites (Table 6). Covariance among transect-level metrics of tree size (mean height, BA, and CWHR class) tended to be low but significant $(0.07<$ Kendall's tau $<0.26, P<0.015)$.

Among our potential metrics of burn severity (Table 5, Additional file 2), we found high and significant correlations between RdNBR, char depth, and snag ratios (Kendall's tau $\geq 0.516, P<0.001)$. However, percent needles retained and bark condition were less correlated with RdNBR, and were instead significantly correlated with fire age (Kendall's tau $\geq 0.152, P \leq 0.027$ ). Snag ratios were most highly correlated with RdNBR (Additional file 3).

\section{Larval woodborer activity}

We rated larval woodborer activity on 2297 dead trees in 443 of 477 plots, including 355 plots within burned 
Table 6 Comparisons of raw data from 11 burned sites and five bark beetle outbreak sites sampled in the greater Sierra Nevada region of California, USA, during the summers of 2015 and 2016, summarized by transect as count ratios or mean \pm standard error. $\mathrm{BBO}=$ bark beetle outbreak, $\mathrm{BA}=$ basal area, $\mathrm{DBH}=$ diameter at breast height

\begin{tabular}{|c|c|c|}
\hline Feature $^{a}$ & Burned sites & BBO sites \\
\hline Dominant tree taxon (count ratio) & Yellow pine $(2.71: 1)$ & White fir (1.48:1) \\
\hline BA $\left(m^{2} h a^{-1}\right)^{* *}$ & $31.69 \pm 1.27$ & $39.28 \pm 2.59$ \\
\hline Snag BA $\left(\mathrm{m}^{2} h \mathrm{~h}^{-1}\right)^{* *}$ & $14.87 \pm 1.31$ & $11.20 \pm 1.20$ \\
\hline Mean DBH $(\mathrm{cm})^{\mathrm{ns}}$ & $46.17 \pm 1.22$ & $45.42 \pm 1.52$ \\
\hline Snag mean DBH $(\mathrm{cm})^{\text {ns }}$ & $42.38 \pm 1.26$ & $44.45 \pm 2.27$ \\
\hline Larval sampling snag DBH $(\mathrm{cm})^{* *}$ & $36.55 \pm 1.23$ & $40.54 \pm 1.50$ \\
\hline Bark beetle presence per quadrat ${ }^{* * *}$ & $0.61 \pm 0.04$ & $1.46 \pm 0.05$ \\
\hline Larval woodborer activity per quadrat ${ }^{\text {ns }}$ & $1.99 \pm 0.08$ & $1.74 \pm 0.12$ \\
\hline Adult buprestids captured $(n)^{\text {ns }}$ & $1.00 \pm 0.12$ & $0.88 \pm 0.11$ \\
\hline Adult cerambycids captured $(n)^{\text {ns }}$ & $0.72 \pm 0.07$ & $0.90 \pm 0.11$ \\
\hline
\end{tabular}

sites and 88 plots within $\mathrm{BBO}$ sites; in the remaining 34 plots, no dead trees were available for sampling. Larvae collected were identified as buprestids $(n=158)$, cerambycids $(n=221)$, bark beetles $(n=223)$, and a variety of less frequent taxa $(n=162)$. Larval woodborer activity (Table 4) was evident mainly from galleries, frass or boring dust, and exit or transit holes, rather than direct observations of larvae. Although these indirect signs were sufficient for distinguishing larval woodborers from other taxa, they were often insufficient for differentiating woodborers by family due to intermingled galleries of unrelated taxa and deterioration of the inner bark and sapwood interface on older snags. Based on these data, the activity per quadrat of all larval woodborers combined was similar between burned and BBO sites for data summarized at the transect level (Table 6).

Our null model of larval activity for burned sites included nested random effects of site, transect, and tree. We omitted plot effects because they explained $<5 \%$ of the random variance and because larval activity was sampled without repeated measures. A fixed effect of survey year (2015 or 2016) was not supported $\left(\Delta_{\text {Null }}=-1.84\right)$, nor were fixed or random effects of burn year $\left(\Delta_{\text {Null }} \leq-5.43\right)$. For BBO sites, our null model of larval activity included a fixed effect of site ( $n=5$ sites), as well as nested random effects of transect, plot, and tree.

Adding our predictor variables (Table 5) one at a time to the null model for each site disturbance type revealed some similarities in the significant predictors of larval activity between site types. Apparent effects of tree taxon and bark beetle presence were similar in burned and BBO sites (Fig. 3). Regardless of disturbance type, larval woodborer activity was highest in yellow pine (hereafter, pine), followed by true fir (fir) and incense-cedar (cedar) (Fig. 3a). Lower activity was recorded in quadrats where bark beetle activity was present (Fig. 3b). Larval activity was significantly higher on smaller trees in burned sites (where small and large trees were sampled equally) but not in BBO sites (where there were few small trees available for sampling) (Fig. 3c). Bark aspect had a significant but minor effect on larval activity after fire, and no significant effect in BBO sites (Fig. 3d).

Model rankings confirmed the support for negative effects of bark beetle activity on larval woodborer activity in both burned and BBO sites. In burned sites (Table 7), the top four models of larval activity confirmed support for effects of bark beetle activity, host tree taxon, tree size, and bark aspect, as in the often simpler models used to generate Fig. 3. In the fifth-ranked model, there was also support for linear and quadratic effects of fire ignition date, with negative effects suggesting lower larval activity in fires ignited at earlier and (especially) later dates during our study period. Support was much higher, however, for effects that we associated with hypotheses related to larval development, resource quality, and competitive interactions within the host resource.

In $\mathrm{BBO}$ sites, site was confounded with tree taxon and bark beetle activity (Additional file 4), reducing our ability to confirm these effects. Nonetheless, the BBO site richest in pine and with lowest bark beetle activity showed much higher activity of woodborer larvae $(12.11 \pm 0.01$ per plot $)$ than other BBO sites $(8.05 \pm 0.01)$, and negative effects of bark beetle activity were included in models ranked 1 and 5 (Table 8).

Aside from competition, data from BBO sites did not support the same hypotheses as data from burned sites (Table 7); instead, top models from BBO sites were based on potential metrics of disturbance age. Signs of larval activity were more abundant on snags with fewer needles retained, with broken tops, and with loose (as opposed to tight or missing) bark. The lower activity associated with 


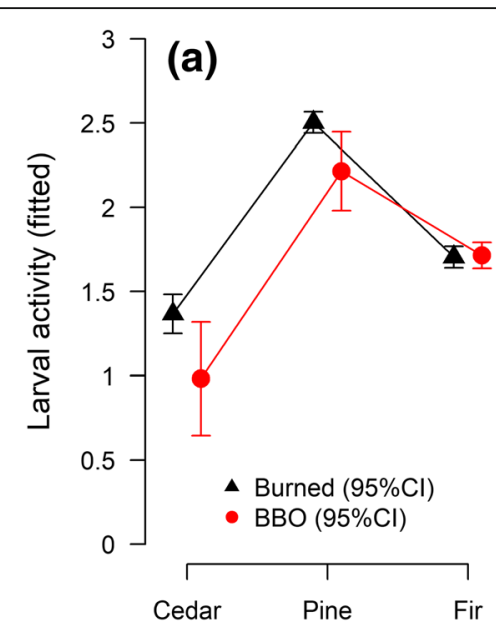

Tree taxon

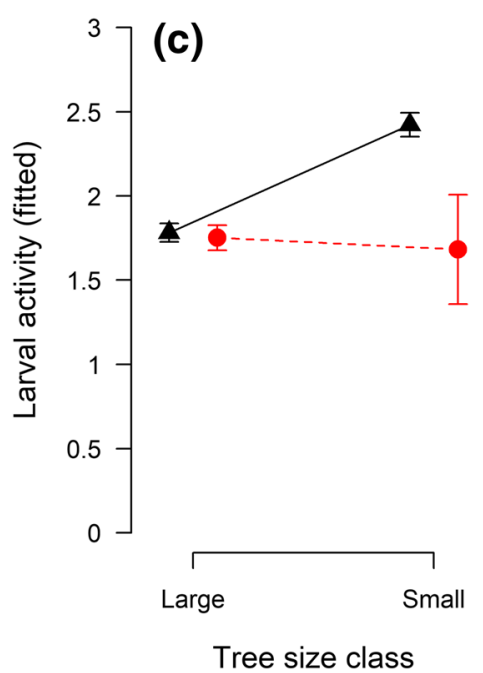

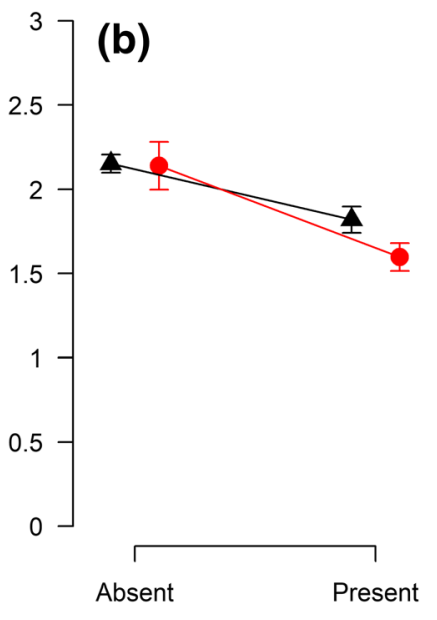

Bark beetle activity

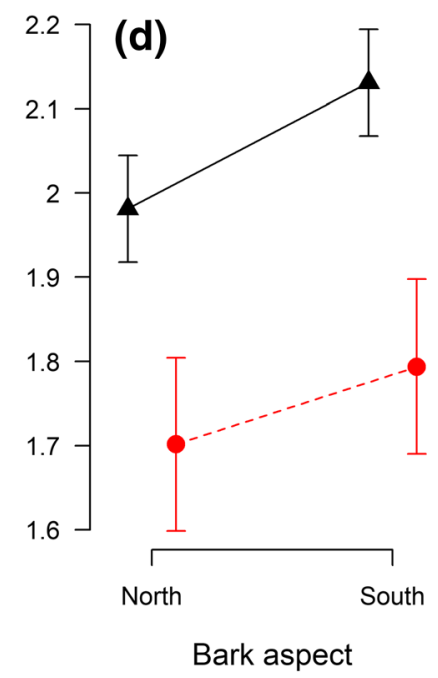

Fig. 3 Larval woodborer activity in burned (black) and bark beetle outbreak (BBO; red) sites in relation to host tree taxon (a), bark beetle activity (b), tree size class at the transect level (c), and aspect of the bark sampling quadrat (d), in the greater Sierra Nevada region of California, USA, sampled during the summers of 2015 and 2016. Point estimates and error bars represent mean responses and 95\% confidence intervals (Cls) from fits to models exemplified in Tables 7 and 8. Dashed lines connect means that do not differ significantly. Response variables are defined in Table 4 and predictor variables are defined in Table 5

missing bark was expected, because signs of activity were sometimes recorded from bark alone. Trees with broken tops might have suffered damage prior to bark beetle outbreaks, allowing more time for woodborer colonization. Needle loss appeared to represent outbreak age, rather than outbreak severity, as bark beetle activity and needles retained were uncorrelated at the transect level within $\mathrm{BBO}$ sites (Kendall's tau = $0.085)$.

\section{Adult woodborer activity}

We identified 10412 adults belonging to six families: 1718 Buprestidae, 1277 Cerambycidae, 5765 Elateridae,
285 Siricidae, 396 Melandryidae, and 971 Cupedidae. The most frequently captured buprestids were Cypriacis aurulenta Linneaus $1767(n=466)$, Melanophila consputa LeConte $1857(n=200)$, and Chalcophora angulicollis LeConte $1857(n=193)$, while Xylotrechus longitarsus Casey $1912(n=190)$, Monochamus obtusus Casey $1891(n=89)$, and Ortholeptura valida LeConte $1857(n=88)$ were most frequent among cerambycids (Additional file 5). Annual differences in buprestid and cerambycid captures could be explained by site (Additional file 6). Raw capture numbers were similar in burned and $\mathrm{BBO}$ sites for both buprestids and cerambycids (Table 6). 
Table 7 Fixed effects and associated hypotheses $\left(\mathrm{H}_{\mathrm{A}}\right.$ from Table 5) in top models of larval woodborer activity across 11 burned sites sampled in the greater Sierra Nevada region of California, USA, during the summers of 2015 and 2016. AICc = Akaike's information criterion, corrected for small sample size; DOY = day of year; Neg = negative; Pos = positive

\begin{tabular}{|c|c|c|c|c|c|}
\hline Model rank & Predictor & Effect $^{\mathrm{a}}$ & $\triangle \mathrm{AICC}$ & $\Delta_{\text {Null }}$ & $\mathrm{H}_{\mathrm{A}}$ \\
\hline \multirow[t]{2}{*}{1} & Bark beetle activity & $\mathrm{Neg}^{* * *}$ & 0.00 & 115.86 & $C$ \\
\hline & Host tree taxon $=$ pine & $\operatorname{Pos}^{* * *}$ & & & $\mathrm{H}$ \\
\hline \multirow[t]{3}{*}{2} & Host tree taxon $=$ pine & $\operatorname{Pos}^{* * *}$ & 14.93 & 100.93 & $\mathrm{H}$ \\
\hline & Host tree taxon $=$ fir & $\operatorname{Pos}^{\text {ns }}$ & & & $\mathrm{H}$ \\
\hline & Host tree taxon = cedar & $\operatorname{Pos}^{\text {ns }}$ & & & $H$ \\
\hline \multirow[t]{4}{*}{3} & Host tree size-class $=$ small & $\operatorname{Pos}^{* * *}$ & 51.69 & 64.17 & G \\
\hline & Bark aspect = south & $\operatorname{Pos}^{* * *}$ & & & G \\
\hline & Fire age & Pos ${ }^{\text {ns }}$ & & & A \\
\hline & Bark aspect $\times$ Fire age & $\mathrm{Neg}^{* * *}$ & & & $\mathrm{G}, \mathrm{A}$ \\
\hline \multirow[t]{3}{*}{4} & Bark aspect $=$ south & $\operatorname{Pos}^{* * *}$ & 71.91 & 43.95 & G \\
\hline & Longitude & $\operatorname{Pos}^{* * *}$ & & & G \\
\hline & Elevation & Pos ${ }^{\text {ns }}$ & & & G \\
\hline \multirow[t]{4}{*}{5} & Ignition date (DOY) & $\mathrm{Neg}^{*}$ & 107.41 & 8.45 & $P$ \\
\hline & DOY $\times$ DOY & $\mathrm{Neg}^{* *}$ & & & P \\
\hline & Fire age & Pos ${ }^{\text {ns }}$ & & & A \\
\hline & DOY $\times$ DOY $\times$ Fire age & Pos ${ }^{\text {ns }}$ & & & $P, A$ \\
\hline
\end{tabular}

Mixed models of adult activity included nested random effects of site and transect for burned sites, or a fixed effect of site and random effect of transect for BBO sites. Model rankings confirmed predictive effects of bark beetle activity, tree size, and burn severity (Fig. 4), as well as ignition date (Fig. 5), among others (Tables 9, 10, 11).

Except for negative effects of ignition date and fire age, top cerambycid models differed from top buprestid models either in hypotheses supported or direction of effects. For example, Xylotrechus longitarsus activity in

Table 8 Fixed effects and associated hypotheses $\left(\mathrm{H}_{\mathrm{A}}\right.$ from Table 5) in top models of larval woodborer activity across five bark beetle outbreak sites sampled in the greater Sierra Nevada region of California, USA, during the summers of 2015 and 2016. AICc = Akaike's information criterion, corrected; Neg = negative; Pos = positive

\begin{tabular}{|c|c|c|c|c|c|}
\hline Model rank & Predictor & Effect $^{a}$ & $\triangle \mathrm{AICC}$ & $\Delta_{\text {Null }}$ & $\mathrm{H}_{\mathrm{A}}$ \\
\hline \multirow[t]{2}{*}{1} & Bark beetle activity & $\mathrm{Neg}^{* *}$ & 0.00 & 20.22 & C \\
\hline & Needles retained & $\mathrm{Neg}^{* * *}$ & & & A \\
\hline 2 & Needles retained & $\mathrm{Neg}^{* * *}$ & 5.37 & 14.85 & A \\
\hline \multirow[t]{2}{*}{3} & Bark condition $=$ tight & $\mathrm{Neg}^{* * *}$ & 7.73 & 12.49 & A \\
\hline & Bark condition $=$ missing & $\mathrm{Neg}^{*}$ & & & A \\
\hline 4 & Broken-top tree $=$ true & $\operatorname{Pos}^{* *}$ & 12.73 & 7.49 & A \\
\hline 5 & Bark beetle activity & $\mathrm{Neg}^{* *}$ & 13.90 & 6.32 & C \\
\hline
\end{tabular}

burned stands supported strong positive effects of latitude-adjusted elevation (Table 10) that were not supported by buprestids (Table 9), and Monochamus Dejean 1821 species supported strong effects of burn severity but were more common in stands burned at low to moderate severity (Table 10), in contrast with buprestid Melanophila consputa (Table 9).

Across multiple buprestid and cerambycid taxa, we found support for negative linear and quadratic effects of ignition date as well a negative effect of fire age and a positive interaction between fire age and the quadratic effect of ignition date. Buprestid data also repeatedly supported the burn severity hypothesis.

For buprestid captures in BBO sites (Table 11), the top model included a negative effect of live tree BA, suggesting support for disturbance magnitude and severity hypotheses. All other models of buprestid and cerambycid adults in BBO sites had much lower relative support and suggested that processes related to habitat quality, larval growth, and competition explained adult activity.

\section{Comparison of larval and adult activity within fires}

We compared fire site effects on larval activity and adult captures by adding a fixed effect of site to null models of larval activity or adult captures. In no case did this effect of site differ in direction between models of larval activity and adult captures. Both larval activity and adult captures were significantly lower than average in samples from the King, Moonlight, and Rim fires (Table 12), which all ignited relatively late in the season (Table 1). At the Washington Fire (1 yr old), larval activity was significantly lower than average but adult captures were moderate. At the Wheeler fire (8 yr old), larval activity was moderate but adult captures were significantly lower than average.

\section{Discussion}

In these montane forests of California, the range of woodborer response to forest conditions suggests that managing for a diversity of disturbance types and severity will support a diverse woodborer community. The different taxa and life stages that we sampled appeared to respond in characteristic ways. Buprestid adults were much more frequent in stands that burned at high severity, a pattern especially evident in Melanophila consputa, which is known for its attraction to heat and smoke (Schmitz et al. 1997; Schütz et al. 1999). In contrast, cerambycids that sense heat and smoke (Monochamus spp.; Álvarez et al. 2015) were more frequent in transects burned at low and moderate severity. Larval activity responded more often to features that might represent the capacity for larval growth and development. Disturbance type, however, appeared to have a relatively minor influence on the activity of most woodborers in our 

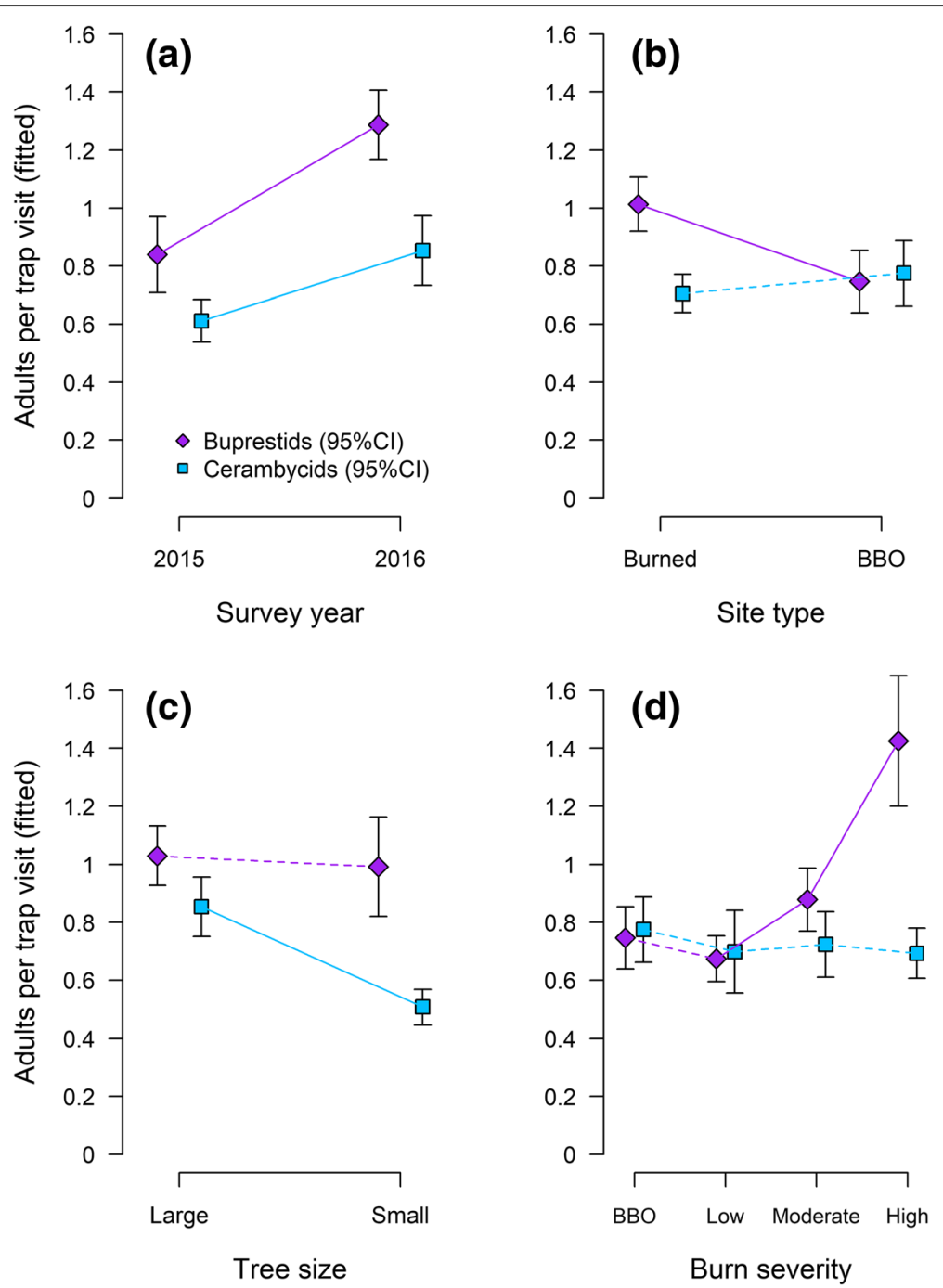

Fig. 4 Adult activity in relation to year (a), site disturbance type (b), tree size class (c), and burn severity (d), shown for two families of woodboring beetles on sites in the greater Sierra Nevada region of California, USA, sampled during the summers of 2015 and 2016. In (d), data from unburned, bark beetle outbreak (BBO) sites are compared with data from sites that burned at low, moderate, or high severity according to RdNBR classifications. Point estimates and error bars represent mean responses and 95\% confidence intervals (Cls) from fits to models exemplified in Tables 9, 10, 11. Dashed lines connect means that do not differ significantly. Response variables are defined in Table 4 and predictor variables are defined in Table 5

study. Except where burn severity was high, cerambycids and buprestids of both stages appeared to occur with similar frequency in burned and BBO sites.

The scale and timing of each analysis should be considered when interpreting an appropriate scope of inference. Burned sites were distributed throughout the Sierra Nevada, while BBO sites were clustered in the northern half of this region, and disturbance type also covaried with disturbance age, because large bark beetle outbreaks had just begun to develop as we initiated the study. We also sampled during a period of extended drought in our study region, when primary and secondary forest pests were likely to be responding in complex ways to stress on the forests in this system (Kolb et al. 2016). Regardless of the unique features of this study, strong patterns were revealed in our data that are likely relevant to many dry coniferous forests that occur throughout the western US. Evidence for these relationships should be investigated for generality in other regions, and across a diversity of fire ages and outbreak sites, to facilitate inferences currently constrained by the naturally high covariance and spatial clustering in values of key predictor variables.

The strong patterns we found, however, can help inform where-and at what scale-management actions might be most effectively applied. Within a disturbed patch of forest, the deliberate retention of pockets or islands of snags with specific characteristics might limit the negative ecological impacts of a reduction in woodborer activity. For example, larval woodborers were 

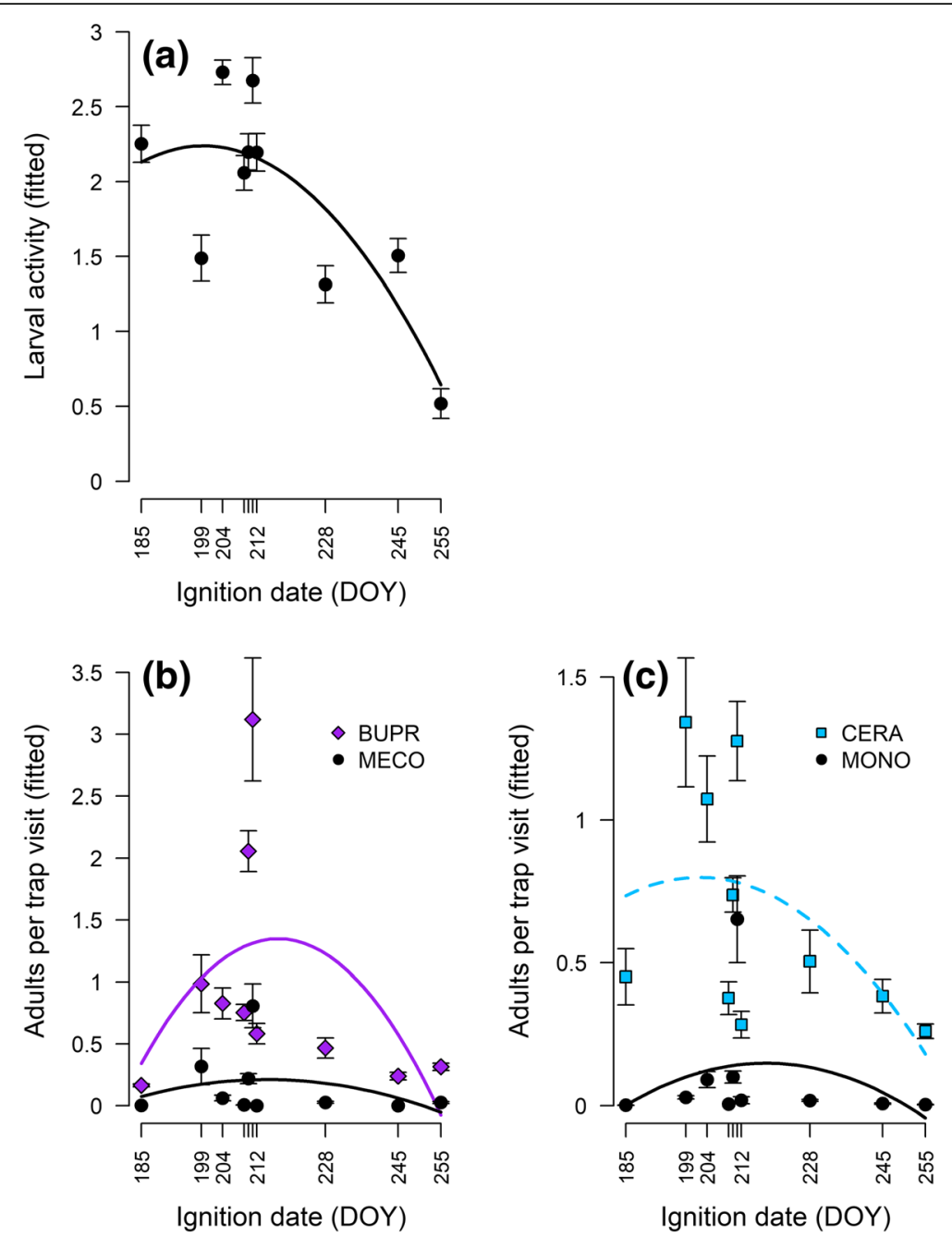

Fig. 5 Activity of larvae (a) and adults (b, c), as defined in Table 4, in relation to fire ignition date (DOY = day of year) at sites in the greater Sierra Nevada region of California, USA, sampled during the summers of 2015 and 2016. Curves represent relationships between squared DOY and fitted point estimates of woodborer response ( $\pm 95 \%$ confidence interval) obtained from linear mixed effects models that included fixed effects of DOY and an interaction between squared DOY and fire age (Tables 7, 9, and 10). BUPR = all buprestids, MECO = Melanophila consputa, CERA = all cerambycids, MONO = Monochamus species. Effects of squared DOY were not supported for CERA. Data from 12 surveys (Table 2) are represented here by only 10 point estimates in each panel because some fires shared the same ignition date (DOY $=210$ for Bald and Frog fires, and DOY $=204$ for 2015 and 2016 samples from the Reading Fire)

more common in particular quadrats where bark beetles were absent, suggesting that the local retention of woodborers might be enhanced by prioritizing retention of trees less heavily infested by bark beetles. Our observations that woodborer larvae were more abundant in smaller pine snags with more southerly exposure, that Xylotrechus Chevrolat 1860 adults were more common where the dominant host tree taxon was true fir, and that Monochamus species were more common where burn severity was low to moderate, can further inform design of snag retention patches that might effectively promote successional processes and provide prey for wildlife species like the black-backed woodpecker (Siegel et al. 2018; Tarbill et al. 2018; Stillman et al. 2019).
The design of post-fire forest management strategies often involves balancing multiple economic and ecological objectives with clear links to woodborer dynamics. Taken together, our results suggest a dynamic process controlling local initiation and accumulation of woodborer activity that likely leads to temporal trends in the faunal communities supported by woodborer larvae and adults as prey and agents of tree decomposition. Beginning with the environment inhabited by larvae, our finding of higher larval activity on smaller trees and southern bark aspects suggests that there are microclimatic effects on larval development. Smaller-diameter trees have thinner bark and lower thermal mass of sap and heartwood, as well as lower sapwood volume (water holding capacity), leading to more 
Table 9 Fixed effects and associated hypotheses $\left(\mathrm{H}_{\mathrm{A}}\right.$ from Table 5$)$ in top models of adult buprestid activity across 11 burned sites sampled in the greater Sierra Nevada region of California, USA, during the summers of 2015 and 2016. QAICc = quasi-Akaike's information criterion, corrected for small sample size; DOY = day of year; Neg = negative; Pos = positive; BA = basal area

\begin{tabular}{|c|c|c|c|c|c|c|}
\hline Response & Model rank & Predictor & Effect $^{a}$ & $\triangle \mathrm{QAICC}$ & $\Delta_{\text {Null }}$ & $\mathrm{H}_{\mathrm{A}}$ \\
\hline \multirow[t]{12}{*}{ Adult buprestid activity } & \multirow[t]{4}{*}{1} & Ignition date (DOY) & $\mathrm{Neg}^{\mathrm{ns}}$ & \multirow[t]{4}{*}{0.00} & \multirow[t]{4}{*}{11.96} & $P$ \\
\hline & & DOY $\times$ DOY & $\mathrm{Neg}^{* * *}$ & & & $\mathrm{P}$ \\
\hline & & Fire age & $\mathrm{Neg}^{* * *}$ & & & A \\
\hline & & DOY $\times$ DOY $\times$ Fire age & $\operatorname{Pos}^{* * *}$ & & & $P, A$ \\
\hline & \multirow[t]{3}{*}{2} & Snag BA & $\operatorname{Pos}^{* *}$ & \multirow[t]{3}{*}{6.17} & \multirow[t]{3}{*}{5.79} & $M, S$ \\
\hline & & Fire age & $\mathrm{Neg}^{* *}$ & & & $A$ \\
\hline & & Snag BA $x$ Fire age & $\operatorname{Pos}^{\text {ns }}$ & & & $M, S, A$ \\
\hline & 3 & Snag BA & $\operatorname{Pos}^{* * *}$ & 6.32 & 5.64 & $M, S$ \\
\hline & 4 & Char height & $\operatorname{Pos}^{* *}$ & 7.57 & 4.39 & S \\
\hline & \multirow[t]{3}{*}{5} & Char height & $\operatorname{Pos}^{* *}$ & \multirow[t]{3}{*}{7.66} & \multirow[t]{3}{*}{4.30} & $S$ \\
\hline & & Fire age & $\mathrm{Neg}^{* *}$ & & & A \\
\hline & & Char height $\times$ Fire age & $\mathrm{Neg}^{\text {ns }}$ & & & $\mathrm{S}, \mathrm{A}$ \\
\hline $\begin{array}{l}\text { Adult Cypriacis aurulenta } \\
\text { activity }^{\mathrm{b}}\end{array}$ & 1 & Host tree taxon = pine & $\operatorname{Pos}^{* *}$ & 0.00 & 0.39 & $\mathrm{H}$ \\
\hline \multirow{17}{*}{$\begin{array}{l}\text { Adult } \\
\text { Melanophila consputa } \\
\text { activity }\end{array}$} & \multirow[t]{4}{*}{1} & Fire age & $\mathrm{Neg}^{* * *}$ & \multirow[t]{4}{*}{0.00} & \multirow[t]{4}{*}{20.19} & A \\
\hline & & Char height & $\operatorname{Pos}^{\mathrm{ns}}$ & & & S \\
\hline & & Live tree BA & $\mathrm{Neg}^{* *}$ & & & $M, S$ \\
\hline & & Ignition date & $\mathrm{Neg}^{* * *}$ & & & $P$ \\
\hline & \multirow[t]{5}{*}{2} & Fire age & $\mathrm{Neg}^{* * *}$ & \multirow[t]{5}{*}{2.33} & \multirow[t]{5}{*}{17.86} & A \\
\hline & & Burn severity $=$ low & $\mathrm{Neg}^{* * *}$ & & & s \\
\hline & & Burn severity $=$ moderate & $\mathrm{Neg}^{* * *}$ & & & S \\
\hline & & Ignition date (DOY) & $\mathrm{Neg}^{*}$ & & & $P$ \\
\hline & & $\mathrm{DOY} \times \mathrm{DOY}$ & $\mathrm{Neg}^{*}$ & & & $P$ \\
\hline & \multirow[t]{4}{*}{3} & Fire age & $\mathrm{Neg}^{* * *}$ & \multirow[t]{4}{*}{3.84} & \multirow[t]{4}{*}{16.35} & $A$ \\
\hline & & Char height & $\operatorname{Pos}^{* * *}$ & & & S \\
\hline & & Ignition date (DOY) & $\mathrm{Neg}^{*}$ & & & $P$ \\
\hline & & $\mathrm{DOY} \times \mathrm{DOY}$ & $\mathrm{Neg}^{*}$ & & & $P$ \\
\hline & \multirow[t]{3}{*}{4} & Fire age & $\mathrm{Neg}^{* * *}$ & \multirow[t]{3}{*}{4.46} & \multirow[t]{3}{*}{15.73} & A \\
\hline & & Burn severity $=$ low & $\mathrm{Neg}^{* * *}$ & & & S \\
\hline & & Burn severity $=$ moderate & $\mathrm{Neg}^{* *}$ & & & $S$ \\
\hline & 5 & Live tree $\mathrm{BA}$ & $\mathrm{Neg}^{* * *}$ & 7.55 & 12.64 & $M, S$ \\
\hline
\end{tabular}

${ }^{\mathrm{a}} \mathrm{ns}(P>0.05),{ }^{*}(P<0.05),{ }^{* *}(P<0.01),{ }^{* * *}(P<0.001)$

${ }^{b}$ Only one model of adult Cypriacis aurulenta activity was supported relative to the null model

rapid desiccation of phloem tissue (Six et al. 2002; Hayes et al. 2008). Southern bole aspect would intensify these microclimatic conditions, likely creating a more favorable environment for rapid larval development. An inverse relationship between tree size and larval woodborer activity was also noted by Powell (2000) in the northern Rocky Mountains. Hanks (1999) suggested that phloem-boring larvae might be especially vulnerable to moisture conditions because they are embedded in the tissues of their host plant, and sensitivity to bark moisture could account for the association between drought stress and host susceptibility that is typical for many phloem-boring insects, especially cerambycid beetles. Thatcher (1961) reported that drought conditions can enable a larger number of cerambycid larvae to survive in systems in which adults attempt to attack living trees. Subcortical and sapwood temperatures in trees and logs exposed to sunlight can be 5 to $30{ }^{\circ} \mathrm{C}$ greater than shaded portions, and these warmer temperatures can decrease the larval development time of phloem-feeding woodborers by 1 to 2 yr (Graham 1925, Savely 1939, Hosking 1977; reviewed in Kariyanna et al. 2017). Alternatively, these patterns could be related to adult female selection of oviposition locations, although we found no evidence of such selectivity in the literature. 
Table 10 Fixed effects and associated hypotheses ( $\mathrm{H}_{\mathrm{A}}$ from Table 5$)$ in top models of adult cerambycid activity across 11 burned sites sampled in the greater Sierra Nevada region of California, USA, during the summers of 2015 and 2016. QAICC = quasi-Akaike's information criterion, corrected for small sample size; DOY = day of year; Neg = negative; Pos = positive; BA = basal area

\begin{tabular}{|c|c|c|c|c|c|c|}
\hline Response & Model rank & Predictor & Effect $^{a}$ & $\triangle \mathrm{QAICC}$ & $\Delta_{\text {Null }}$ & $\mathrm{H}_{\mathrm{A}}$ \\
\hline Adult cerambycid activity & 1 & Null & & 0.00 & 0.00 & \\
\hline \multirow{8}{*}{$\begin{array}{l}\text { Adult } \\
\text { Xylotrechus longitarsus activity }\end{array}$} & \multirow[t]{3}{*}{1} & Fire age & $\mathrm{Neg}^{* *}$ & \multirow[t]{3}{*}{0.00} & \multirow[t]{3}{*}{4.66} & A \\
\hline & & Elevation & $\operatorname{Pos}^{* * *}$ & & & G \\
\hline & & Ignition date & $\mathrm{Neg}^{\text {ns }}$ & & & $P$ \\
\hline & 2 & Elevation & $\operatorname{Pos}^{* * *}$ & 0.02 & 4.64 & G \\
\hline & 3 & Host tree taxon $=$ fir & $\operatorname{Pos}^{* *}$ & 0.76 & 3.90 & $\mathrm{H}$ \\
\hline & \multirow[t]{2}{*}{4} & Elevation & $\operatorname{Pos}^{* * *}$ & \multirow[t]{2}{*}{2.04} & \multirow[t]{2}{*}{2.62} & G \\
\hline & & Elevation $^{2}$ & $\operatorname{Pos}^{\text {ns }}$ & & & G \\
\hline & 5 & Snag BA & $\operatorname{Pos}^{* * *}$ & 2.68 & 1.98 & $M, S$ \\
\hline \multirow[t]{15}{*}{ Adult Monochamus species activity } & \multirow[t]{3}{*}{1} & Fire age & $\mathrm{Neg}^{*}$ & \multirow[t]{3}{*}{0.00} & \multirow[t]{3}{*}{9.06} & $A$ \\
\hline & & Burn severity $=$ low & $\operatorname{Pos}^{* *}$ & & & S \\
\hline & & Burn severity $=$ moderate & $\operatorname{Pos}^{* * *}$ & & & $S$ \\
\hline & \multirow[t]{2}{*}{2} & Burn severity $=$ low & $\operatorname{Pos}^{* *}$ & \multirow[t]{2}{*}{1.35} & \multirow[t]{2}{*}{7.71} & $S$ \\
\hline & & Burn severity $=$ moderate & $\operatorname{Pos}^{* * *}$ & & & $S$ \\
\hline & \multirow[t]{4}{*}{3} & Ignition date (DOY) & Neg ${ }^{\text {ns }}$ & \multirow[t]{4}{*}{1.56} & \multirow[t]{4}{*}{7.50} & $P$ \\
\hline & & DOY $\times$ DOY & $\mathrm{Neg}^{\mathrm{ns}}$ & & & $P$ \\
\hline & & Fire age & $\mathrm{Neg}^{* * *}$ & & & $A$ \\
\hline & & DOY $\times$ DOY $\times$ Fire age & $\operatorname{Pos}^{* * *}$ & & & $P, A$ \\
\hline & 4 & Needles retained & $\operatorname{Pos}^{* * *}$ & 2.64 & 6.42 & A \\
\hline & \multirow[t]{5}{*}{5} & Fire age & $\mathrm{Neg}^{*}$ & \multirow[t]{5}{*}{3.16} & \multirow[t]{5}{*}{5.90} & A \\
\hline & & Burn severity $=$ low & $\operatorname{Pos}^{* *}$ & & & S \\
\hline & & Burn severity $=$ moderate & $\operatorname{Pos}^{* * *}$ & & & S \\
\hline & & Ignition date (DOY) & $\mathrm{Neg}^{\text {ns }}$ & & & $P$ \\
\hline & & DOY $\times$ DOY & $\mathrm{Neg}^{\mathrm{ns}}$ & & & $P$ \\
\hline
\end{tabular}

$\overline{a_{\text {ns }}(P>0.05),{ }^{*}(P<0.05),{ }^{* *}(P<0.01),{ }^{* * *}(P<0.001)}$

Table 11 Fixed effects and associated hypotheses $\left(H_{A}\right.$ from Table 5$)$ in top models of adult buprestid or cerambycid activity across five bark beetle outbreak sites sampled in the greater Sierra Nevada region of California, USA, during the summer of 2016. QAICc = quasi-Akaike's information criterion, corrected for small sample size; BA = basal area; Neg = negative; Pos = positive; DBH = diameter at breast height

\begin{tabular}{|c|c|c|c|c|c|c|}
\hline Response & Model rank & Predictor (fixed effects) & Effect $^{a}$ & $\Delta \mathrm{QAIC}_{\mathrm{C}}$ & $\Delta_{\text {Null }}$ & $H_{A}$ \\
\hline \multirow[t]{5}{*}{ Adult buprestid activity } & 1 & Live tree $B A$ & $\mathrm{Neg}^{* * *}$ & 0.00 & 25.85 & $M, S$ \\
\hline & 2 & Bark beetle activity & $\operatorname{Pos}^{* *}$ & 20.97 & 4.88 & C \\
\hline & 3 & Elevation & $\mathrm{Neg}^{* *}$ & 21.20 & 4.65 & G \\
\hline & 4 & Longitude & $\mathrm{Neg}^{* *}$ & 21.97 & 3.88 & G \\
\hline & 5 & Needles retained & $\operatorname{Pos}^{* *}$ & 22.36 & 3.49 & A \\
\hline \multirow[t]{5}{*}{ Adult cerambycid activity } & 1 & Host tree taxon $=$ cedar & $\mathrm{Neg}^{* *}$ & 0.00 & 4.02 & $\mathrm{H}$ \\
\hline & 2 & Broken-top tree $=$ true & $\mathrm{Neg}^{* *}$ & 1.00 & 3.02 & A \\
\hline & 3 & DBH & $\mathrm{Neg}^{* *}$ & 1.38 & 2.64 & G \\
\hline & 4 & Host tree taxon $=$ fir & Pos $^{*}$ & 3.46 & 0.56 & $\mathrm{H}$ \\
\hline & 5 & Null & & 4.02 & 0.00 & \\
\hline
\end{tabular}

$\overline{\mathrm{ans}}(P>0.05),{ }^{*}(P<0.05),{ }^{* *}(P<0.01),{ }^{* * *}(P<0.001)$ 
Table 12 Fixed effects of burned site on larval and adult woodborer activity across 11 burned sites sampled in the greater Sierra Nevada region of California, USA, during the summers of 2015 and 2016. Neg = negative; Pos = positive

\begin{tabular}{llll}
\hline $\begin{array}{l}\text { Burned site } \\
\text { (fire name) }\end{array}$ & Fire age (yr) & \multicolumn{2}{l}{ Fixed effect on activity } \\
\cline { 3 - 4 } & & Larval model & Adult model $^{{ }^{*}}$ \\
\hline Eiler & 1 & $\mathrm{~ns}$ & Pos $^{* *}$ \\
Krog & 1 & $\mathrm{~ns}$ & $\mathrm{~ns}$ \\
Wing & 1 & $\mathrm{Neg}^{* * *}$ & $\mathrm{Neg}^{* *}$ \\
Bald & 1 & $\mathrm{Neg}^{*}$ & $\mathrm{~ns}$ \\
Rim & 2 & $\mathrm{~ns}^{*}$ & $\mathrm{Pos}^{*}$ \\
Reading (2015) & 3 & $\mathrm{Neg}^{* * *}$ & $\mathrm{Neg}^{*}$ \\
Reading (2016) & 4 & $\mathrm{Pos}^{* *}$ & $\mathrm{~ns}$ \\
Chips & 4 & $\mathrm{~ns}^{*}$ & $\mathrm{~ns}$ \\
Sugarloaf & 6 & $\mathrm{~ns}$ & $\mathrm{~ns}$ \\
Moonlight & 8 & $\mathrm{~ns}$ & $\mathrm{~ns}$ \\
Wheeler & 8 & $\mathrm{Neg}$ & $\mathrm{Neg}^{*}$ \\
\hline
\end{tabular}

${ }^{a}$ ns $(P>0.05),{ }^{*}(P<0.05),{ }^{* *}(P<0.01),{ }^{* * *}(P<0.001)$

The inverse relationship between bark beetle and larval woodborer activity that we observed was likely due to competition for phloem resources or other factors affecting adult or larval microhabitat partitioning among beetle species. Because woodboring beetles typically colonize dead and dying trees, such as those killed or weakened by bark beetles, the nutrient-rich phloem resource can be greatly reduced by bark beetle activity prior to colonization by woodboring beetles, limiting its availability for larval woodborer development (Coulson et al. 1979; Powell 2000). Thus, variation in the availability of phloem for woodboring beetle larvae could depend on the timing of bark beetle attack versus woodborer colonization. For example, the western pine beetle (Dendroctonus brevicomis Erichson 1836) produces more than one generation per year (Miller and Keen 1960), which might allow these bark beetles to attack trees outside the peak flight period for woodboring beetles. If bark beetles attack trees in the weeks or months before woodborer dispersal, the resource might be depleted before woodborer eggs hatch. If bark beetles attack trees after woodborer dispersal, changes in the resource during the ensuing year might combine with resource depletion to make trees unattractive or unsuitable for some woodboring beetles. Alternatively, tree size can play a role in competition with bark beetles such as the fir engraver (Scolytus ventralis LeConte 1868), which tends to attack higher on the bole of larger-diameter trees, leaving the lower portions of the bole available for woodboring beetles (Ferrell and Hall 1975). In addition, because primary bark beetles avoid fire-killed trees, especially those with foliage completely scorched or consumed, the phloem resource in fire-killed trees might often be more available for woodboring beetle colonization (Parker et al. 2006). In contrast, competition with secondary bark beetles, such as Ips De Geer 1775 spp., in fire-killed trees may occur in the upper boles and limbs of larger trees and all portions of smaller trees. This is especially true for secondary bark beetles attacking thicker-barked tree species such as those sampled in this study. However, Costello (2013) found that no bark beetles emerged from fire-killed tree bolts, even though outbreaks of the mountain pine beetle (Dendroctonus ponderosae Hopkins 1902) were abundant near the fires in that study.

Costello (2013) also found significantly more woodborers emerging from fire-killed trees than from trees killed by bark beetles, in contrast with our finding of similar woodborer activity in burned and BBO stands. This contrast could reflect a difference in the timing of post-fire monitoring between their study of fires 1 to $2 \mathrm{yr}$ old and our study of fires 1 to 8 yr old. Furthermore, bark beetle activity was common in our burned sites, occurring in over $30 \%$ of bark samples. Some snags in older burned sites might have been killed by bark beetles attacking fire-stressed trees in the years following a burn (Davis et al. 2012), reducing the distinction between burned and BBO sites as a food resource for woodboring beetles. Potential similarities in post-disturbance ecology of burned and $\mathrm{BBO}$ sites warrant further investigation.

Fire age also helped explain the pattern of adult captures. For all but one taxon modeled in burned sites, adult capture numbers declined with fire age, as expected if older fires were less attractive to dispersing adults or less productive as source habitats for these species. Data from buprestids (especially M. consputa) and cerambycids (Monochamus species) also supported a positive interaction between fire age and squared ignition date. Although these species were more common at burned sites with intermediate ignition dates, those fires did not appear to act as long-term sources of these species in the landscape. This dynamic process should lead to temporal trends in the faunal communities woodborers support. Indeed, black-backed woodpecker abundance in burned forests in California generally peaks within five years after fire, followed by sharp declines (Tingley et al. 2018).

Our results also suggest that there are competing influences of disturbance age. Adult woodborers might cue on current signs of a snag-producing disturbance, but signs of larval activity accumulate over time, so we might expect stronger or opposing effects of disturbance age on adult captures when compared with larval activity. In fact, we found a positive effect of fire age on the combined activity of larval woodborer species, but negative effects of fire age 
on captures of adult $M$. consputa, X. longitarsus, and Monochamus species, as well as all adult buprestids combined. Negative effects of fire age were most evident for M. consputa, as expected for members of a genus notably adapted for detecting fires in progress. Emerging adults of species that are attracted to fire might often emigrate, seeking fires in progress and reducing local recruitment that would otherwise tend to obscure a negative relationship between fire age and adult captures. We found negative effects of fire age on both buprestids (especially $M$. consputa) and cerambycids (Monochamus species) despite allowing up to eight years of post-fire recruitment, suggesting that there is low incidence of local recruitment in these species. Other woodborers less attracted to heat and smoke might be more likely to colonize trees that succumb to post-fire processes (Angers et al. 2011), such as bark beetle attack.

Finally, the effects of fire ignition date deserve special consideration in further analyses of woodboring beetle ecology. We found surprisingly consistent support across life stages and taxa for negative linear and quadratic relationships between ignition date and woodborer activity, suggesting that there is a temporal peak and decline in the efficacy of woodborer colonization following forest disturbances. The relatively late-season King, Moonlight, and Rim fires provided important support for this apparent effect that should be investigated for generality. Throughout the western US, fire season has lengthened substantially in recent decades (Abatzoglou and Williams 2016; Westerling 2016), due to changes in climate as well as increasing anthropogenic ignitions, which often occur well outside the range of dates associated with lightning ignitions (Balch et al. 2017). This lengthening of the fire season is expected to continue and perhaps even accelerate in the coming decades (Yue et al. 2013, Westerling 2016), yielding more fires that ignite outside the optimal period for driving woodborer population growth and the ecosystem processes that depend on woodborers.

However, we caution that our analysis is based on only 11 fires with a relatively modest spread in ignition dates (5 July to 13 September). Only two of these fires ignited earlier than the interquartile range of lightning ignition dates reported by Balch et al. (2017) for an area that includes the Sierra Nevada, and only two others ignited later than the interquartile range. Furthermore, ignition date is at best a rough index of burn date for the specific areas that we surveyed with our transects. We therefore cannot pinpoint thresholds in ignition date that are likely to yield robust colonization by woodborers, nor can we state with certainty that the apparent effect of ignition date in this study does not stem from another process associated with site. Rather, we view the pervasive effect of ignition date in our models as a starting point for further research on this topic.

\section{Conclusions}

Woodboring beetle activity at our study sites was often similar between burned stands and unburned stands damaged by bark beetles, but varied dramatically with stand composition, burn severity, and the intensity of bark beetle activity associated with each type of disturbance. In burned sites, the relationship between woodborer activity and ignition date suggested that increased prevalence of wildfire might not increase woodboring beetle populations if fires increasingly occur outside the historical fire season. Effects of these patterns on ecological processes like snag longevity and woodpecker activity should be further explored to inform decisions about management of disturbed forest stands. The patterns observed in this study should be investigated for generality in other regions, and across a diversity of fires and bark beetle outbreaks, to facilitate inference in this system, which naturally exhibits high covariance and spatial clustering in the values of key predictor variables.

\section{Additional files}

Additional file 1: Spatial data sources used to guide transect placement in burned (a-f) and bark beetle outbreak (a-e, g) sites in the greater Sierra Nevada region of California, USA, during the summers of 2015 and 2016. (PDF $107 \mathrm{~kb}$ )

Additional file 2: Correlations (Kendall's tau) among potential metrics of burn severity and fire age, 1 to 8 years post burn, from 11 California wildfires in the greater Sierra Nevada region of California, USA, that burned during the summers of 2015 and 2016. BA = basal area, RdNBR = Relative differenced Normalized Burn Ratio. (PDF $119 \mathrm{~kb}$ )

Additional file 3: Comparison of the Relative differenced Normalized Burn Ratio (RdNBR) with metrics of burn severity measured in the field (panels $\mathrm{a}-\mathrm{c}$ ), and correlations between burn severity metrics based on snag ratios (d), from 11 burned sites and five bark beetle outbreak (BBO) sites in the greater Sierra Nevada region of California, USA, sampled during the summers of 2015 and 2016. Points represent transect-level averages. $\mathrm{BA}=$ basal area. (PDF $591 \mathrm{~kb}$ )

Additional file 4: Tree species composition (a) and indices of bark beetle activity (b) in bark beetle outbreak (BBO) sites in the greater Sierra Nevada region of California, USA, sampled during the summers of 2015 and 2016. The Reading BBO site differed markedly in tree composition and bark beetle activity, and was also lowest in elevation (see main text, Table 3) and lowest in latitude-adjusted elevation (mean \pm SE $=1901.10$ $\pm 0.07 \mathrm{~m}$ for Reading $\mathrm{BBO}, 2354.13 \pm 0.03 \mathrm{~m}$ for other $\mathrm{BBO}$ sites). $\mathrm{BA}=$ basal area. (PDF $796 \mathrm{~kb}$ )

Additional file 5: Buprestids (a) and cerambycids (b) identified from unbaited beetle traps operated during June to August of 2015 and 2016 in burned and bark beetle outbreak sites within mixed-conifer montane forests in the greater Sierra Nevada region of California, USA. (PDF 862 kb)

Additional file 6: Adult buprestid and cerambycid captures per trap visit averaged by day of year from 11 burned sites and five bark beetle outbreak sites in the greater Sierra Nevada region of California, USA sampled during the summers of 2015 and 2016. Trends by day of year were not significant after accounting for effects of year. Differences in raw captures per trap visit between years for buprestids $(0.82 \pm 0.17$ in 
2015 and $1.14 \pm 0.11$ in 2016) and cerambycids (0.63 \pm 0.08 in 2015 and $0.88 \pm 0.09$ in 2016) were not significant after accounting for effects of site. (PDF $1113 \mathrm{~kb})$

\section{Acknowledgements}

We thank IBP field crews (A. Marquez, D. Mauer, M. Lerow, J. Rivera, C. Seay, M. Seeley, and B. Wiesner) and USFS staff (B. Bualon, M. Easton, A. Eglitis, M Johnson, R. Mahnke, A. Nelson, K. Ripley, S. Smith, and B. Woodruff) for help with this project, which was funded by USFS Region 5 and the Evaluation Monitoring component of the USFS Forest Health Monitoring program. Manuscript development benefited greatly from two anonymous reviews. This is Contribution No. 624 of The Institute for Bird Populations.

\section{Funding}

Funding for this research was provided by the USDA Forest Service through the Forest Health Monitoring Program (Evaluation Monitoring), Pacific Southwest Region, and Forest Health Protection Program.

\section{Availability of data and materials}

Data and materials used in this study are available from the corresponding author upon reasonable request.

\section{Authors' contributions}

DRC, RLW, RBS, AMW, and CAH conceived and designed the study. DRC, RLW, RBS, AMW, and GLT collected the data. CR analyzed the data and drafted the manuscript with input from DRC, RLW, RBS, AMW, GLT, SCS, and $\mathrm{CAH}$. All authors approved the final manuscript.

\section{Ethics approval and consent to participate}

Not applicable.

\section{Consent for publication}

Not applicable.

\section{Competing interests}

The authors declare that they have no competing interests.

\section{Publisher's Note}

Springer Nature remains neutral with regard to jurisdictional claims in published maps and institutional affiliations.

\section{Author details}

${ }^{1}$ The Institute for Bird Populations, P.O. Box 1346, Point Reyes Station, California 94956, USA. ${ }^{2}$ USDA Forest Service, Forest Health Protection, 2550 Riverside Drive, Susanville, California 96130, USA. ${ }^{3}$ USDA Forest Service, Pacific Southwest Research Station, 1731 Research Park Drive, Davis, California 95618, USA. ${ }^{4}$ USDA Forest Service, Pacific Southwest Region, 1323 Club Drive, Vallejo, California 94592, USA. ${ }^{5}$ USDA Forest Service, Pacific Southwest Research Station, 800 Buchanan Street, Albany, California 94710, USA.

Received: 21 December 2018 Accepted: 8 May 2019

Published online: 05 July 2019

\section{References}

Abatzoglou, J.T., and A.P. Williams. 2016. Impact of anthropogenic climate change on wildfire across western US forests. Proceedings of the National Academy of Sciences of the USA 113: 11770-11775 https://doi.org/10.1073/ pnas.1607171113.

Álvarez, G., B. Ammagarahalli, D.R. Hall, J.A. Pajares, and C. Gemeno. 2015. Smoke, pheromone and kairomone olfactory receptor neurons in males and females of the pine sawyer Monochamus galloprovincialis (Olivier)(Coleoptera: Cerambycidae). Journal of Insect Physiology 82: 46-55 https://doi.org/10.1016/ j.jinsphys.2015.08.004

Angers, V.A., S. Gauthier, P. Drapeau, K. Jayen, and Y. Bergeron. 2011. Tree mortality and snag dynamics in North American boreal tree species after a wildfire: a long-term study. International Journal of Wildland Fire 20: 751-763 https://doi.org/10.1071/WF10010.
Arnett, R.H., Jr., M.C. Thomas, P.E. Skelley, and J.H. Frank, editors. 2002. American beetles, volume II: Polyphaga: Scarabaeoidea through Curculionoidea, illustrated. Boca Raton: CRC Press https://doi.org/10.1201/9781420041231.

Aukema, J.E., B. Leung, K. Kovacs, C. Chivers, K.O. Britton, J. Englin, S.J. Frankel, R.G. Haight, T.P. Holmes, A.M. Liebhold, D.G. McCullough, and B. Von Holle. 2011. Economic impacts of non-native forest insects in the continental United States. PLoS ONE 6: e24587 https://doi.org/10.1371/journal.pone.0024587.

Aukema, J.E., D.G. McCullough, B. Von Holle, A.M. Liebhold, K. Britton, and S.J. Frankel. 2010. Historical accumulation of nonindigenous forest pests in the continental United States. Bioscience 60: 886-897 https://doi.org/10.1525/bio. 2010.60.11.5.

Balch, J.K., B.A. Bradley, J.T. Abatzoglou, R.C. Nagy, E.J. Fusco, and A.L. Mahood 2017. Human-started wildfires expand the fire niche across the United States. Proceedings of the National Academy of Sciences of the USA 114: 2946-2951 https://doi.org/10.1073/pnas.1617394114.

Bates, D., M. Maechler, B.M. Bolker, and S.C. Walker. 2015. Fitting linear mixedeffects models using Ime4. Journal of Statistical Software 67: 1-48 https://doi. org/10.18637/jss.v067.i01.

Bentz, B.J., J. Régnière, C.J. Fettig, E.M. Hansen, J.L. Hayes, J.A. Hicke, R.G. Kelsey, J. F. Negrón, and S.J. Seybold. 2010. Climate change and bark beetles of the western United States and Canada: direct and indirect effects. BioScience 60: 602-613 https://doi.org/10.1525/bio.2010.60.8.6.

Bohlman, G.N., M. North, and H.D. Safford. 2016. Shrub removal in reforested post-fire areas increases native plant species richness. Forest Ecology and Management 374: 195-210 https://doi.org/10.1016/j.foreco.2016.05.008.

Boisramé, G., S. Thompson, B. Collins, and S. Stephens. 2016. Managed wildfire effects on forest resilience and water in the Sierra Nevada. Ecosystems 20 (4): 717-732 https://doi.org/10.1007/s10021-016-0048-1.

Brin, A., and C. Bouget. 2018. Biotic interactions between saproxylic insect species. In Zoological monographs 1. Saproxylic insects. Edited by M. Ulyshen. Pages 471-514. Chamonix: Springer.

Brock, B.L., and R.M. Inman. 2006. Use of latitude-adjusted elevation in broadscale species distribution models. Intermountain Journal of Sciences 12: 12-17.

Burnham, K.P., and D.R. Anderson. 2002. Model selection and multi-model inference: a practical information-theoretic approach, second edition. New York: SpringerVerlag.

California Department of Fish and Game. 2005. California Wildlife Habitat Relationships (CWHR), version 8.1. Sacramento: California Department of Fish and Game.

Collins, B.M., and G.B. Roller. 2013. Early forest dynamics in stand-replacing fire patches in the northern Sierra Nevada, California, USA. Landscape Ecology 28: 1801-1813 https://doi.org/10.1007/s10980-013-9923-8.

Coppoletta, M., K.E. Merriam, and B.M. Collins. 2016. Post-fire vegetation and fuel development influences fire severity patterns in reburns. Ecological Applications 26: 686-699 https://doi.org/10.1890/15-0225.

Costello, S.L. 2013. Emergence of Buprestidae, Cerambycidae, and Scolytinae (Coleoptera) from mountain pine beetle-killed and fire-killed ponderosa pines in the Black Hills, South Dakota, USA. The Coleopterists Bulletin 67 (2): 149-154 https://doi.org/10.1649/0010-065X-67.2.149.

Costello, S.L., J.F. Negrón, and W.R. Jacobi. 2011. Wood-boring insect abundance in fire-injured ponderosa pine. Agricultural and Forest Entomology 13: 373381 https://doi.org/10.1111/j.1461-9563.2011.00531.x.

Coulson, R., P. Pulley, and L. Edson. 1979. Sampling considerations for evaluating the effects of mortality agents on bark beetles. In The role of insectivorous birds in forest ecosystems. Edited by J.G. Dickson, R.N. Conner, R.R. Fleet, J.A. Jackson, and J.C. Kroll. New York: Academic Press https://doi.org/10.1016/ B978-0-12-215350-1.50009-0.

Coulson, R.N., A.M. Mayyasi, J.L. Foltz, and F.P. Hain. 1976. Interspecific competition between Monochamus titillator and Dendroctonus frontalis. Environmental Entomology 5: 235-247 https://doi.org/10.1093/ee/5.2.235.

Cranshaw, W.S., D.A. Leatherman, W.R. Jacobi, and L. Mannix. 2000. Insects and diseases of woody plants of the Central Rockies. Bulletin 506A. Fort Collins: Colorado State University Cooperative Extension Service.

Davis, R.S., S. Hood, and B.J. Bentz. 2012. Fire-injured ponderosa pine provide a pulsed resource for bark beetles. Canadian Journal of Forest Research 42: 2022-2036 https://doi.org/10.1139/×2012-147.

Dennison, P.E., S.C. Brewer, J.D. Arnold, and M.A. Moritz. 2014. Large wildfire trends in the western United States, 1984-2011. Geophysical Research Letters 41: 2928-2933 https://doi.org/10.1002/2014GL059576.

Diffenbaugh, N.S., D.L. Swaina, and D. Touma. 2015. Anthropogenic warming has increased drought risk in California. Proceedings of the National Academy of Sciences of the USA 112: 3931-3936 https://doi.org/10.1073/pnas.1422385112. 
Dodds, K.J., C. Graber, and F.M. Stephen. 2001. Facultative intraguild predation by larval Cerambycidae (Coleoptera) on bark beetle larvae (Coleoptera: Scolytidae). Environmental Entomology 30: 17-22 https://doi.org/10.1603/ 0046-225X-30.1.17

Eklund, A., M.G. Wing, and J. Sessions. 2009. Evaluating economic and wildlife habitat considerations for snag retention policies in burned landscapes. Western Journal of Applied Forestry 24: 67-75.

Evans, A.V., and J.N. Hogue. 2006. Field guide to beetles of California. Berkeley: University of California Press.

Ferrell, G.T., and R.C. Hall. 1975. Weather and tree growth associated with white fir mortality caused by fir engraver and roundbeaded fir borer. Research Paper PSW-109. Berkeley: USDA Forest Service, Pacific Southwest Forest and Range Experimental Station.

Foelker, C.J., D. Parry, and M.K. Fierke. 2018. Biotic resistance and the spatiotemporal distribution of an invading woodwasp, Sirex noctilio. Biological Invasions 20: 1991-2003 https://doi.org/10.1007/s10530-018-1673-8.

Furniss, R.L., and V.M. Carolin. 1977. Western forest insects. Miscellaneous Publication No. 1339. Washington, D.C.: USDA Forest Service https://doi.org/ 10.5962/bhl.title.131875.

Gardiner, L.M. 1957. Deterioration of fire-killed pine in Ontario and the causal wood-boring beetles. The Canadian Entomologist 98: 241-263 https://doi.org/ 10.4039/Ent89241-6.

Graham, M.L. 2003. Confronting multicollinearity in ecological multiple regression. Ecology 84: 2809-2815 https://doi.org/10.1890/02-3114.

Graham, S.A. 1925. The felled tree trunk as an ecological unit. Ecology 6: 397-411 https://doi.org/10.2307/1929106

Hanks, L.M. 1999. Influence of the larval host on reproductive strategies of cerambycid beetles. Annual Review of Entomology 44: 483-505 https://doi. org/10.1146/annurev.ento.44.1.483.

Harrington, T.C. 1993. Biology and taxonomy of fungi associated with bark beetles. In Beetle-pathogen interactions in conifer forests. Edited by T.D. Schowalter and G.M. Filip, 38-58. New York: Academic Press.

Hayes, C.J., T.E. DeGomeza, J.D. McMillin, J.A. Anhold, and R.W. Hofstetter. 2008 Factors influencing pine engraver (Ips pini Say) colonization of ponderosa pine (Pinus ponderosa Dougl. ex. Laws.) slash in northern Arizona. Forest Ecology and Management 255: 3541-3548 https://doi.org/10.1016/j.foreco.2008.02.037.

Hosking, G.P. 1977. Arhopalus ferus, the influence of subcortical temperature on development and growth. New Zealand Journal of Forestry Science 7: 3-15.

Ikeda, T., N. Enda, A. Yamane, K. Oda, and T. Toyoda. 1980. Attractants for the Japanese pine sawyer, Monochamus alternatus Hope (Coleoptera: Cerambycidae). Applied Entomology and Zoology 15: 358-361 https://doi.org/ 10.1303/aez.15.358

Jacobsen, R.M., T. Birkemoe, and A. Sverdrup-Thygeson. 2015. Priority effects of early successional insects influence late successional fungi in dead wood. Ecology and Evolution 5: 4896-4905 https://doi.org/10.1002/ece3.1751.

Kahl, T., T. Arnstadt, K. Baber, C. Bässler, J. Bauhus, W. Borken, F. Buscot, A. Floren, C. Heibl, D. Hessenmöller, M. Hofrichter, B. Hoppe, H. Kellner, D. Krüger, K.E. Linsenmair, E. Matzner, P. Otto, W. Purahong, C. Seilwinder, E.-D. Schulze, B. Wende, W.W. Weisser, and M.M. Gossner. 2017. Wood decay rates of 13 temperate tree species in relation to wood properties, enzyme activities and organismic diversities. Forest Ecology and Management 391: 86-95 https://doi. org/10.1016/j.foreco.2017.02.012.

Kariyanna, B., M. Mohan, and R. Gupta. 2017. Biology, ecology and significance of longhorn beetles (Coleoptera: Cerambycidae). Journal of Entomology and Zoology Studies 5: 1207-1212.

Kelsey, R.G., and G. Joseph. 2003. Ethanol in ponderosa pine as an indicator of physiological injury from fire and its relationship to secondary beetles. Canadian Journal of Forest Research 33: 870-884 https:/doi.org/10.1139/x03-007.

Kitzberger, T., D.A. Falk, A.L. Westerling, and T.W. Swetnam. 2017. Direct and indirect climate controls predict heterogeneous early-mid $21^{\text {st }}$ century wildfire burned area across western and boreal North America. PLOS ONE 12 (12): e0188486 https://doi.org/10.1371/journal.pone.0188486.

Kolb, T.E., C.J. Fettig, M.P. Ayres, B.J. Bentz, J.A. Hicke, R. Mathiasen, J.E. Stewart, and A.S. Weed. 2016. Observed and anticipated impacts of drought on forest insects and diseases in the United States. Forest Ecology and Management 380: 321-334 https://doi.org/10.1016/j.foreco.2016.04.051.

LaBonte, J.R., S.A. Valley, and C. Niwa. 2013a. Screening aid for the Buprestidae of the western USA. Version 082913. Oregon Department of Agriculture and USDA Forest Service, Portland. https://www.oregon.gov/ ODA/programs/IPPM/InsectsSpiders/Pages/Identifylnsect.aspx. Accessed 11 Nov 2018.
LaBonte, J.R., S.A. Valley, J. Vlach, C. Niwa. 2013b. Screening aid for the Cerambycidae of the western U.S.A. Version 032315. Oregon Department of Agriculture and USDA Forest Service. https://www.oregon.gov/ODA/ programs/IPPM/InsectsSpiders/Pages/Identifylnsect.aspx. Accessed 11 Nov 2018.

Littell, J.S., D. Mckenzie, D.L. Peterson, and A.L. Westerling. 2009. Climate and wildfire area burned in western US ecoprovinces, 1916-2003. Ecological Applications 19: 1003-1021 https://doi.org/10.1890/07-1183.1.

Lowell, E.C., and J.M. Cahill. 1996. Deterioration of fire-killed timber in southern Oregon and northern California. Western Journal of Applied Forestry 11 (4): 125-130.

Marini, L., B. Økland, A.M. Jönsson, B. Bentz, A. Carroll, B. Forster, J.-C. Grégoire, R. Hurling, L.M. Nageleisen, S. Netherer, H.P. Ravn, A. Weed, and M. Schroeder. 2017. Climate drivers of bark beetle outbreak dynamics in Norway spruce forests. Ecography 40: 1426-1435 https://doi.org/10.1111/ecog.02769.

Miller, D.R. 2006. Ethanol and (-)-a-pinene: attractant kairomones for some large wood-boring beetles in southeastern USA. Journal of Chemical Ecology 32: 779-794 https://doi.org/10.1007/s10886-006-9037-8.

Miller, J.D., E.E. Knapp, C.H. Key, C.N. Skinner, C.J. Isbell, R.M. Creasy, and J. W. Sherlock. 2009b. Calibration and validation of the Relative differenced Normalized Burn Ratio (RdNBR) to three measures of fire severity in the Sierra Nevada and Klamath Mountains, California, USA. Remote Sensing of Environment 113: 645-656 https://doi.org/10.1016/j. rse.2008.11.009.

Miller, J.D., and B. Quayle. 2015. Calibration and validation of immediate post-fire satellite-derived data to three severity metrics. Fire Ecology 11 (2): 12-30 https://doi.org/10.4996/fireecology.1102012.

Miller, J.D., H.D. Safford, M.A. Crimmins, and A.E. Thode. 2009a. Quantitative evidence for increasing forest fire severity in the Sierra Nevada and southern Cascade Mountains, California and Nevada, USA. Ecosystems 12: 16-32 https://doi.org/10.1007/s10021-008-9201-9.

Miller, J.M., and F.P. Keen. 1960. Biology and control of the western pine beetle: $a$ summary of the first 50 years of research. Miscellaneous Publication 800. Washington, D.C.: USDA Forest Service.

Murphy, E.C., and W.A. Lehnhausen. 1998. Density and foraging ecology of woodpeckers following a stand-replacement fire. Journal of Wildlife Management 62: 1359-1372 https://doi.org/10.2307/3802002.

Parker, T.J., K.M. Clancy, and R.L. Mathiasen. 2006. Interactions among fire, insects and pathogens in coniferous forests of the interior western United States and Canada. Agricultural and Forest Entomology 8: 167-189 https://doi.org/10. 1111/j.1461-9563.2006.00305.x.

Powell, H. 2000. The influence of prey density on post-fire habitat use of the black-backed woodpecker. Master's thesis. Missoula: University of Montana.

Powell, H.D.W., S.J. Heil, and D.L. Six. 2002. Measuring woodpecker food: a simple method for comparing wood-boring beetle abundance among fire-killed trees. Journal of Field Ornithology 73: 130-140 https://doi.org/10.1648/02738570-73.2.130.

R Core Team. 2016. R: a language and environment for statistical computing. Vienna: R Foundation for Statistical Computing https://www.R-project.org/.

Raffa, K.F., B.H. Aukema, B.J. Bentz, A.L. Carroll, J.A. Hicke, M.G. Turner, and W.H. Romme. 2008. Cross-scale drivers of natural disturbances prone to anthropogenic amplification: the dynamics of bark beetle eruptions. BioScience 58: 501-517 https://doi.org/10.1641/B580607.

Ryan, K.C. 1982. Techniques for assessing fire damage to trees. In: Fire, its field effects. Proceedings of the 1982 joint fire council meeting, Jackson, Wyoming, 19-21 October. Edited by J.E. Lotan. Pages 1-10. Missoula, Montana, USA: The Intermountain Fire Council, and Pierre, South Dakota, USA: The Rocky Mountain Fire Council

Saracco, J.F., R.B. Siegel, and R.L. Wilkerson. 2011. Occupancy modeling of blackbacked woodpeckers on burned Sierra Nevada forests. Ecosphere 2 (3): art31 https://doi.org/10.1890/ES10-00132.1.

Savely, H.E. 1939. Ecological relations of certain animals in dead pine and oak logs. Ecological Monographs 9: 321-385 https://doi.org/10.2307/1943233.

Schiff, N.M., S.A. Valley, J.R. LaBonte, and D.R. Smith. 2006. Guide to the siricid woodwasps of North America. Morgantown: USDA Forest Service, Forest Health Technology Enterprise Team https://www.fs.fed.us/foresthealth/ technology/pdfs/GuideSiricidWoodwasps.pdf Accessed 11 Nov 2018.

Schmitz, H., H. Bleckmann, and M. Mürtz. 1997. Infrared detection in a beetle. Nature 386: 773-774 https://doi.org/10.1038/386773a0.

Schütz, S., B. Weissbecker, H.E. Hummel, K.-H. Apel, H. Schmitz, and H. Bleckmann. 1999. Insect antenna as a smoke detector. Nature 398: 298-299 https://doi. org/10.1038/18585. 
Seager, R., M. Ting, I. Held, Y. Kushnir, J. Lu, G. Vecchi, H.-P. Huang, N. Harnik, A. Leetmaa, N.-C. Lau, C. Li, J. Velez, and N. Naik. 2007. Model projections of an imminent transition to a more arid climate in southwestern North America. Science 316: 1181-1184 https://doi.org/10.1126/science.1139601.

Siegel, R.B., M.L. Bond, C.A. Howell, S.C. Sawyer, and D.L. Craig, editors. 2018. A conservation strategy for the black-backed woodpecker (Picoides arcticus) in California. Version 2.0. Point Reyes Station: The Institute for Bird Populations and California Partners in Flight.

Six, D.L., M. Vander Meer, T.H. DeLuca, and P. Kolb. 2002. Pine engraver (Ips pini) colonization of logging residues created using alternative slash management systems in western Montana. Western Journal of Applied Forestry 17: 96-100.

Stillman, A.N., R.B. Siegel, R.L. Wilkerson, M. Johnson, and M.W. Tingley. 2019. Agedependent habitat relationships of a burned forest specialist emphasise the role of pyrodiversity in fire management. Journal of Applied Ecology 56 (4): 880-890 https://doi.org/10.1111/1365-2664.13328.

Tarbill, G.L., A.M. White, and P.N. Manley. 2018. The persistence of black-backed woodpeckers following delayed salvage logging in the Sierra Nevada. Avian Conservation and Ecology 13 (1): 16 https://doi.org/10.5751/ACE-01206130116.

Taylor, A.H., A.M. Vandervlugt, R.S. Maxwell, R.M. Beaty, C. Airey, and C.N. Skinner 2014. Changes in forest structure, fuels and potential fire behaviour since 1873 in the Lake Tahoe Basin, USA. Applied Vegetation Science 17: 17-31 https://doi.org/10.1111/avsc.12049.

Thatcher, T.O. 1961. Forest entomology. Minneapolis: Burgess Publishing

Tingley, M.W., and S.R. Beissinger. 2013. Cryptic loss of montane avian richness and high community turnover over 100 years. Ecology 94: 598-609 https:// doi.org/10.1890/12-0928.1.

Tingley, M.W., A.N. Stillman, R.L. Wilkerson, C.A. Howell, S.C. Sawyer, and R.B. Siegel. 2018. Cross-scale occupancy dynamics of a postfire specialist in response to variation across a fire regime. Journal of Animal Ecology 87: 1484-1496 https://doi.org/10.1111/1365-2656.12851.

Villard, P., and C.W. Beninger. 1993. Foraging behavior of male black-backed and hairy woodpeckers in a forest burn. Journal of Field Ornithology 64: 71-76.

Westerling, A.L. 2016. Increasing western US forest wildfire activity: sensitivity to changes in the timing of spring. Philosophical Transactions of the Royal Society B 371: 20150178 https://doi.org/10.1098/rstb.2015.0178.

Westerling, A.L., H.G. Hidalgo, D.R. Cayan, and T.W. Swetnam. 2006. Warming and earlier spring increase western US forest wildfire activity. Science 313: 940 943 https://doi.org/10.1126/science.1128834.

White, A.M., P.N. Manly, G.L. Tarbill, T.W. Richardson, R.E. Russell, H.D. Safford, and S.Z. Dobrowski. 2015. Avian community responses to post-fire forest structure: implications for fire management. Animal Conservation 19: 256-264 https://doi.org/10.1111/acv.12237.

Williams, A.P., C.D. Allen, A.K. Macalady, D. Griffin, C.A. Woodhouse, D.M. Meko, T. W. Swetnam, S.A. Rauscher, R. Seager, H.D. Grissino-Mayer, J.S. Dean, E.R. Cook, C. Gangodagamage, M. Cai, and N.G. McDowell. 2013. Temperature as a potent driver of regional forest drought stress and tree mortality. Nature Climate Change 3: 292-297 https://doi.org/10.1038/nclimate1693.

Yue, X., L.J. Mickley, J.A. Logan, and J.O. Kaplan. 2013. Ensemble projections of wildfire activity and carbonaceous aerosol concentrations over the western United States in the mid-21st century. Atmospheric Environment 77: 767-780 https://doi.org/10.1016/j.atmosenv.2013.06.003.

\section{Submit your manuscript to a SpringerOpen ${ }^{\circ}$ journal and benefit from:}

- Convenient online submission

- Rigorous peer review

- Open access: articles freely available online

- High visibility within the field

- Retaining the copyright to your article

Submit your next manuscript at $\boldsymbol{\nabla}$ springeropen.com 